\title{
ARCYRIA VERSICOLOR OF WESTERN MOUNTAINS, U.S.A. (MYXOMYCETES: TRICHIALES: TRICHIACEAE): A MORPHOLOGICAL AND TAXONOMIC STUDY WITH OBSERVATIONS OF NIVICOLOUS SPECIES
}

\author{
Harold W. Keller \\ Botanical Research Institute of Texas \\ 1700 University Dr. \\ Fort Worth, Texas 76107-3400, U.S.A. \\ haroldkeller@hotmail.com \\ corresponding author
}

\section{Billy G. Stone}

Botanical Research Institute of Texas 1700 University Dr.

Fort Worth, Texas 76107-3400, U.S.A.

\author{
Relf L. Price \\ Los Alamos National Laboratory \\ PO Box 1663 \\ Los Alamos, New Mexico 87545, U.S.A. \\ relf@lanl.gov
}

Edward D. Forrester

Botanical Research Institute of Texas 1700 University Dr.

Fort Worth, Texas 76107-3400, U.S.A.

\section{ABSTRACT}

Arcyria versicolor (Trichiales: Trichiaceae) is a distinct myxomycete species described by William Phillips in 1877. The genus Arcyria dates back to Linnaeus in 1753 through the species A. denudata. Arcyria sporangia are brightly colored red, yellow, grey or white, mostly stalked, often in large groups easily seen with the naked eye. Approximately 54 species are known, many are common, and distributed worldwide. Collectors often encounter these colorful species on decaying logs as clusters of many sporangia often covering extensive areas. Arcyria versicolor, collected in the Valles Caldera National Preserve located in the Jemez Mountains of north central New Mexico, is a new record for the state. The nomenclatural history of this species is reviewed and the justification for selection of the species name versicolor is discussed. Arcyria versicolor is accepted as the valid species name and A. vitellina a synonym after examination of type specimens. Environmental parameters for coloration are discussed in general for fruiting bodies of Arcyria and more specifically for nivicolous snowbank species. Transitional stages of plasmodial color to mature fruiting body formation are described for Arcyria versicolor. More than 140 specimens of Arcyria versicolor fruiting bodies were examined with light microscopy and in part illustrated with multifocal computer stacked imaging. Higher magnifications were highlighted using scanning electron microscopy. A more complete and accurate species description is provided for Arcyria versicolor. Differences of fruiting body morphology including habit, color, dehiscence, peridial inner and outer surface features, capillitial ornamentation and size, spore color, size, and ornamentation, and stalk spore-like bodies are described and illustrated. Observation of type specimens from the type locality is illustrated, discussed, and nomenclatural evaluation given for the name selected. Mountain myxomycetes are reviewed based on the observations of T.H. Macbride and his early 1914 paper published in Mycologia. Collection data is presented that compares the dark-spored and light spored nivicolous myxomycetes in the French Alps. The history of renown collectors of nivicolous myxomycetes in western mountains of U.S.A. documents the discovery and study of this special ecological group of myxomycetes. This current paper is the first in a series from an ongoing research project entitled Myxomycetes of New Mexico.

Key WorDs: capillitium, computer stacking, fruiting bodies, Jemez Mountains, New Mexico, scanning electron microscopy, snowbank slime molds, sporangia, Valles Caldera National Preserve

\section{RESUMEN}

Arcyria versicolor (Trichiales: Trichiaceae) es una especie de myxomycete descrita por William Phillips en 1877. El género Arcyria existe desde Linneo en 1753 mediante la especie A. denudata. Los esporangios de Arcyria presentan colores brillantes rojo, amarillo, gris o blanco, casi siempre pedicelados, a menudo en grupos grandes que se ven con facilidad a simple vista. Se conocen unas 54 especies, muchas de ellas son comunes, y de distribución cosmopolita. Los colectores encuentran a menudo estas especies coloridas sobre troncos en descomposición como grupos de muchos esporangios que frecuentemente cubren áreas extensas. Arcyria versicolor, colectada en la Reserva Nacional Valles Caldera localizada en las Montañas Jemez del centro-norte de Nuevo México, es una cita nueva para el estado. Se revisa la historia nomenclatural de esta especie y se discute la justificación por la selección del epíteto específico versicolor. Arcyria versicolor se acepta como el nombre específico correcto y A. vitellina como sinónimo después de examinar los especímenes tipo. Se discuten los parámetros ambientales para la coloración para los cuerpos fructíferos de Arcyria y más específicamente para las especies nivícolas. Se describe la transición de los estados del color plasmodial hasta la formación del cuerpo fructífero maduro de Arcyria versicolor. Se examinaron los cuerpos fructíferos de más de 140 especímenes de Arcyria versicolor al microscopio óptico y en parte se ilustraron con imagen multifocal apilada. Los aumentos más grandes se pusieron de manifiesto usando microscopio electrónico de barrido. Se aporta una descripción más completa y precisa de 
Arcyria versicolor. Se describen e ilustran las diferencias morfológicas de los cuerpos fructíferos incluyendo hábito, color, dehiscencia, características de la superficie peridial interna y externa, ornamentación del capilicio y tamaño, color de la espora, tamaño, y ornamentación, y cuerpos pedunculares esporiformes. Se discute y se ilustra la observación de los especímenes la localidad del tipo, y se da una evaluación nomenclatural para el nombre seleccionado. Los myxomycetes de montaña se revisan basados en las observaciones de T.H. Macbride y su artículo temprano de 1914 publicado en Mycologia. Se presentan los datos de colección que compara los es myxomycetes nivícolas de esporas oscuras y de esporas claras en los Alpes franceses. La historia de colectores prestigiosos de myxomycetes nivícolas en las montañas del oeste de U.S.A. documenta el descubrimiento y estudio de este grupo ecológico especial de myxomycetes. Este actual artículo es el primero de una serie de un proyecto de investigación en marcha titulado Myxomycetes de Nuevo México.

\section{INTRODUCTION}

The Myxomycetes of New Mexico has been an ongoing research project since 1969 when Relf L. Price (RLP) made many of his collections in the Jemez Mountains of northern New Mexico (Price 1971). He identified 255 myxomycete collections, representing 49 species, including 31 species that were new records for New Mexico. His Master of Science thesis was submitted to Utah State University in 1971. These records were never published in a scientific journal.

Subsequently hundreds of field trips by RLP, and occasionally accompanied by Ted Stampfer, both longtime residents of New Mexico, and Harold W. Keller (HWK) from Texas, resulted in additional myxomycete species collected over the intervening years. Among these additional species collected was included Arcyria versicolor Phill., a new record for the state of New Mexico and the Valles Caldera National Preserve (VCNP) located in the Jemez Mountains of north-central New Mexico (Figs. 1A-F).

\section{The Valles Caldera National Preserve}

The geological and human history, aerial map, habitats represented by scenic vistas, and some nivicolous (snowbank) myxomycetes highlighted by Lamproderma cristatum Meyl. were part of a published article about the VCNP (Price et al. 2010). Collecting trips to this area (Figs. 1A-H) resulted in many snowbank myxomycete species representing new state records for Lamproderma and a species new to science (Fig. 1F) Comatricha calderaensis R. Price, G. Moreno, \& A. Castillo (Moreno et al. 2008). A recent publication by Moreno et al. (2019) provides color habit photographs, light photomicrographs (LMs), and scanning electron micrographs (SEMs) of some Lamproderma species collected outside the VCNP and sent to him by Ted Stampfer. Some of these collections were made by HWK and at that time were recognized as New Mexico state records for Lamproderma echinosporum Meyl. and Meriderma cribrarioides (Fr.) Mar. Mey. \& Poulain.

Historically, the VCNP was the Baca Location No.1 of the Land Grant System established by the governments of Spain and Mexico. The property was privately owned by various people and families until the summer of 2000 when purchased by the US government as part of the National Forest System. It was overseen by the US Forest Service and VCNP and was an experiment to become a self-sustaining property as a "working ranch." In 2004, RLP, was granted a research permit titled, "The Cryptogam Project." A volunteer team led by RLP endeavored to inventory and study the myxomycetes, fleshy fungi, plant fungal parasites, algae, bryophytes and lichens. In 2015 the preserve was transferred from the National Forest Service to the National Park Service (Fig. 1A).

Volcanic activity began in the area about 16 million years ago creating calderas followed by more recent violent volcanic eruptions about 1.4 to 1 million years ago creating resurgent domes (Redondo Peak, Figs. 1B, $\mathrm{C}$ and Redondito. The most recent eruption about 60,000 years ago created the landscapes and habitats seen today that features a number of cerros (Spanish for mound, hill or dome), valleys, and bowl-shaped crater extending $22 \mathrm{~km}$ from rim to rim (Fig. 1B). Valles Caldera means "Valleys of the Cauldron" in Spanish that resulted in the present-day beautiful grassland landscapes such as the Valle Grande near the south entrance. The highest point in the VCNP is Redondo Peak at 3,431 m (Fig. 1C). Near this area the specimen of Arcyria versicolor sporangia was found during the field trip of 7 May 2005 (Figs. 1B, G).

\section{Purpose of publication}

Confusion associated with the names Arcyria versicolor W. Phill. and A. vitellina W. Phill. taxonomic status will be evaluated and discussed based on study of the type specimens on loan from the NYBG. Specimens of 
Arcyria versicolor from western U.S.A. states were observed using the light microscope (LM) and scanning electron microscope (SEM). to document a more complete and detailed morphological description of the species. Renown American mycological collectors, dating from the early 1900s, will be highlighted based on collections deposited with the National Fungus Collections (BPI, Fig. 2), Denver Botanic Garden (DBG, Fig. 2) and the NYBG, (Figs. 8A, 9A). Iconography will include multifocal imaging of habit photographic images that document color variation along with discussion of environmental conditions that influence color changes over time. Collections from high elevations in western U.S.A. were examined and evaluated to determine if Arcyria versicolor was either a facultative or obligate nivicolous myxomycete species. Assessment here of mountain myxomycetes, a paper by Macbride (1914), overlooked by most myxomycetologists, contains observations related to the occurrence of nivicolous myxomycetes in western U.S.A. mountains with particular reference to Arcyria versicolor.

\section{METHODOLOGY}

\section{Light microscope observations}

Tools for preparing fruiting bodies for slide-making such as dissecting needles, air blowers, and forceps are described in detail by Sundberg and Keller (1996); Keller and Braun (1999); Keller and Marshall (2019). Microscope glass slides with a frosted end were used to make mounts of myxomycete structures for identification. Small handmade pins attached to wooden handles were used to remove fruiting bodies from the substratum. A droplet of clear lactophenol was placed in the center of the microscope slide, sporangia were added, and a square cover slip was gradually lowered at an inclined angle over the specimen to avoid creating air bubbles.

Permanent slides were made for future use by sealing the edge of the cover slip with ZUT, a resiniferous slide-ringing compound. Identification labels written in pencil on the frosted end of the slide were covered with clear tape to prevent smudging. Slides were wrapped with lens paper and placed in properly labeled collection boxes. A Nikon Alphaphot light compound microscope was used to scan slides. A calibrated ocular micrometer was used to make measurements to identify myxomycete species (Keller \& Marshall 2019).

Images were taken using a Canon EOS 7D camera with Kenko extension tubes (12 mm, 20 mm, $36 \mathrm{~mm}$ ) and a Canon MP-E $65 \mathrm{~mm}$ lens. A composite image was made using between 10 and 100 separate images. The programs Helicon Remote, version 3.9.7 W, and Helicon Focus, version 7.0.2 Pro (Helicon Soft Ltd.), were used to obtain image stacks and render focused images. Resultant images were then optimized using Adobe Photoshop CC 19.0.

\section{Scanning electron microscope observations}

A pair of fine-pointed forceps was used to transfer sporangia to the SEM stub surface. Observations were made using a Hitachi SU3500 high resolution scanning electron microscope of uncoated specimens. Images were recorded in a reduced contrast mode and processed in Adobe Photoshop to retain highlight information and extract the maximum detail available. Each SEM image has the electron detector used (LED = lower electron detector), working distance, magnification and acc. voltage is noted at the lower edge (Keller \& Marshall 2019).

\section{Preparation of herbarium specimens}

Pieces of decayed conifer wood with fruiting bodies of myxomycete sporangia were removed and glued to the bottom of a collection box (Fig. 1H). Labels included species name, state, county, collection locality, habitat, UTM or GPS coordinates, collection date, collector's name (legit) and accession number, person identifier (fide) were affixed to the box top. All wood and slide specimens were assigned a Botanical Research Institute of Texas (BRIT) barcode number and deposited in the BRIT herbarium (Keller \& Marshall 2019). The Arcyria versicolor collection cited here was found on buried coniferous wood at roadside (Fig. 1G), New Mexico: Sandoval County, VCNP, 2835 m, 7 May 2005 near Redondo Peak, Legit: HWK \#4785, 13S 0359677-3976558, BRIT barcode \#418883.

\section{Classification of Trichiales}

The order Trichiales is one of five orders in the myxomycetes recognized by Martin and Alexopoulos (1969). There are two dark-spored orders (Physarales and Stemonitales), one order with light and dark spores, 

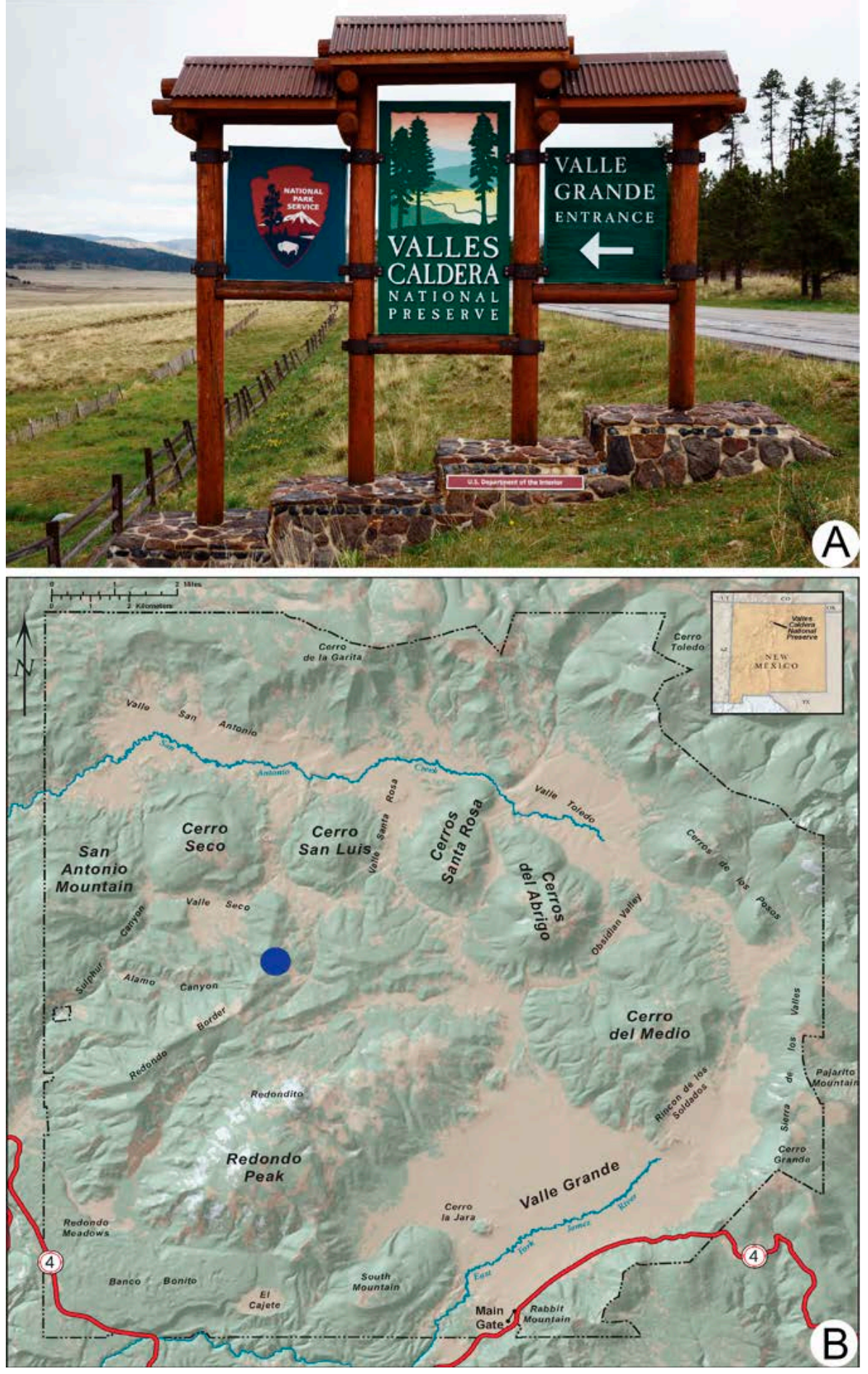

Fig. 1 A-H. Valles Caldera National Preserve. A. Welcome sign at main entrance along New Mexico State Road 4. B. Map highlighting collection site of Arcyria versicolor (blue dot) at 2,835 m elevation UTM location 13S 0359677-3976558. 

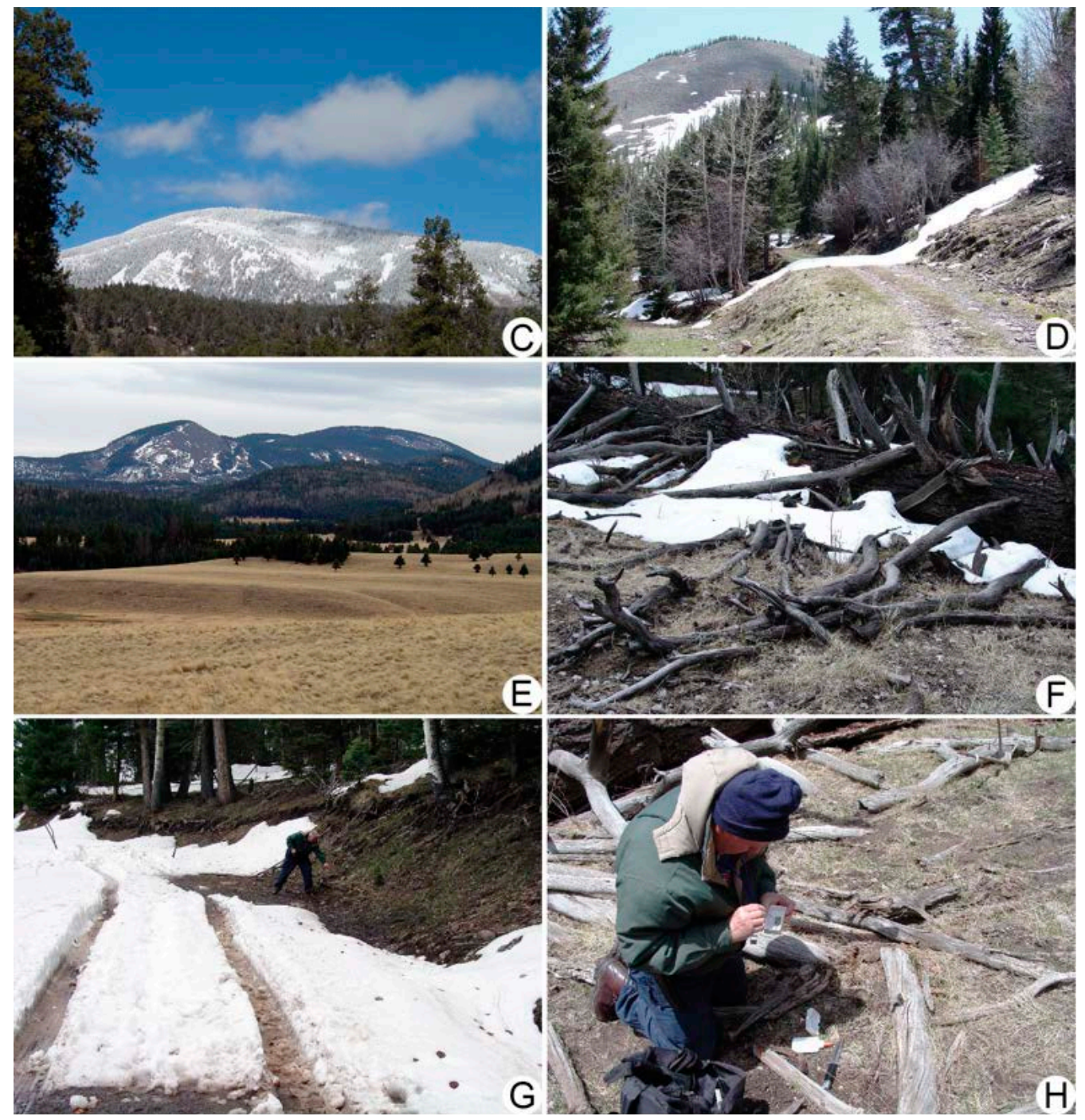

Fig. 1 C-H. C. Southerly face of snow-covered Redondo Peak after early seasonal snow storm. D. Typical collection site for nivicolous myxomycetes along road cut with snow drifts. Redondito in background. E. Spring snow melt of the high elevation resurgent domes, Redondito (on the left) and Redondo Peak (on the right). The gray areas on the mountain slopes are felsenmeer rock fields. F. Large corticated fallen Douglas Fir (Pseudotsuga menziesii) where Comatricha calderaensis and Lamproderma cristatum were collected, at elevation 2,800 m. G. Snow-covered road with vehicle tracks. HWK pointing to conifer log along roadside where Arcyria versicolor was collected. H. HWK collecting nivicolous myxomycetes on scattered decorticated branches.

Liceales, and the light-spored orders Echinosteliales and Trichiales. The Trichiales lack the dark melanin pigments and columella found in other orders. There are two families in the Trichiales: Dianemataceae and Trichiaceae, distinguished mostly by the capillitial threads (lacking a hollow lumen) in the former family, and hollow capillitial threads (hollow lumen) in the latter. The family Trichiaceae has about 12 genera including Arcyria with an elastic expanding capillitial system that forms a tangled network of threads marked with cogs, rings, spines or warts, in plumes above a cup-like base or calyculus. There are approximately 54 Arcyria species recognized as valid by Lado (2005-2020). 


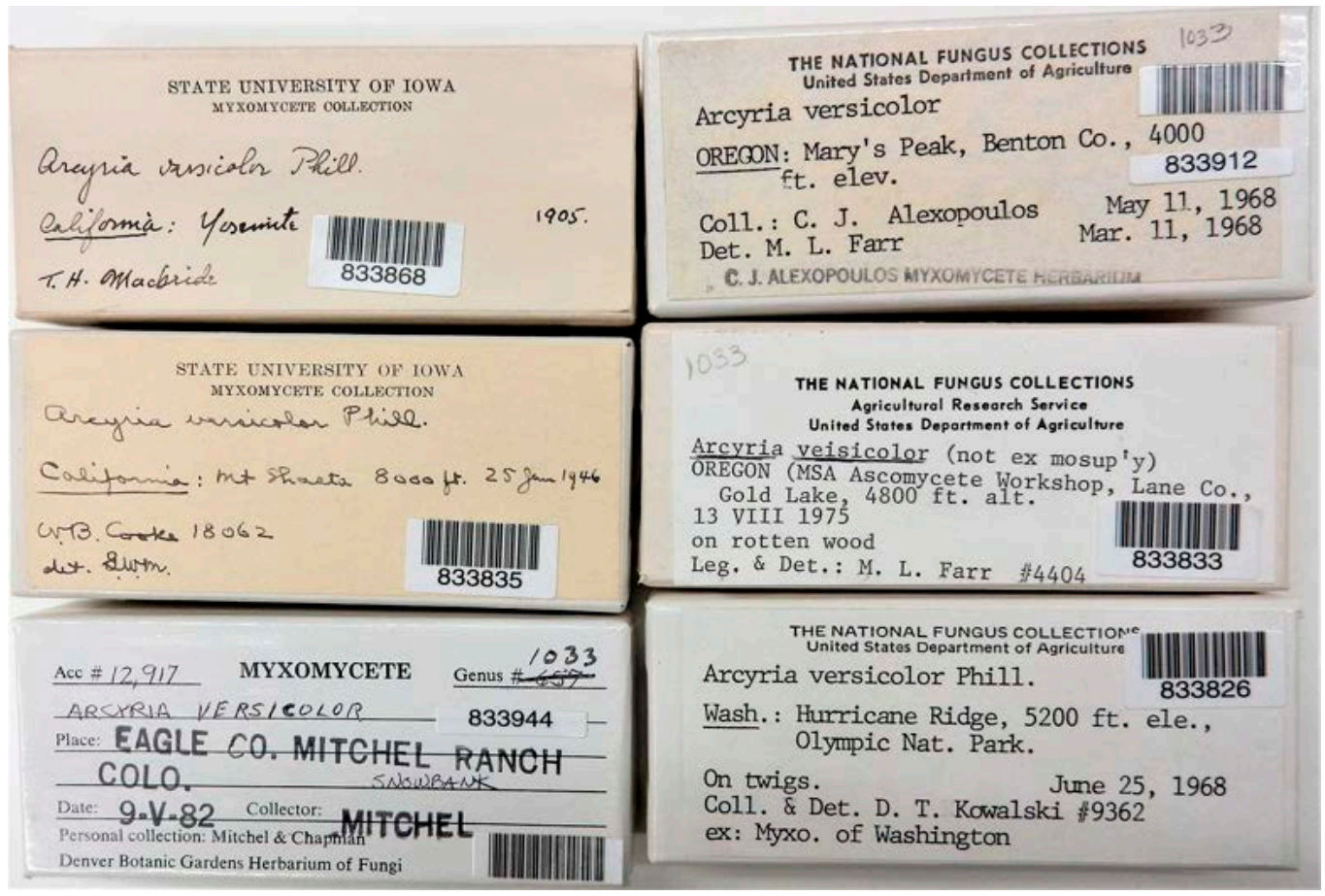

FIG. 2. Noteworthy Arcyria versicolor collections. Box labels arranged alphabetically by state: California, Colorado, Oregon, Washington, representing six renown myxomycete collectors: Thomas H. Macbride, William B. Cooke, Constantine J. Alexopoulos, Marie L. Farr, Donald T. Kowalski, and Duane H. "Sam" Mitchel. All collections are from high elevation western mountainous states including one collection made in 1905 from Yosemite National Park, Sierra Nevada Mountains of Central California. Specimens on loan from BPI and DBG.

\section{Mountain myxomycetes}

One of the earliest volumes published by Mycologia, (Macbride 1914) contains his flowery literary style about the different mountainous regions, comparing the far western states along the west coast (California, Oregon, and Washington) to the midwestern interior mountainous states (New Mexico and Colorado). Macbride's travels took him from Iowa to New Mexico and Colorado on to Yosemite, California and along the coast to Puget Sound and Washington. His life was chronicled by Keller (2012) but unfortunately nothing about his collecting in mountainous regions was included nor was his paper cited by Macbride himself (1922; Macbride \& Martin 1934; Hagelstein 1944; Martin \& Alexopoulos 1969), nor by Kowalski in his many papers published on nivicolous myxomycetes, especially the genus Lamproderma (Kowalski 1975).

Macbride's assessment of the environmental conditions and fruiting of nivicolous myxomycetes merits consideration. He contrasts the dominant species diversity of the genus Physarum in the Rocky Mountains with additional extensive fruitings of calcareous species and the dominance of Lamproderma, Comatricha, and trichiaceous (noncalcareous) species in the Puget Sound and Mount Rainier regions of Washington (Macbride 1914). He also refers to the nivicolous myxomycetes of the far western mountains as being more robust forming extensive fruiting bodies.

Macbride (1922) observes on page 250 and 251 the following "At 7,000 ft. Arcyria vitellina Phill. particularly the form A. versicolor occurs in wide colonies of large sporangia, twice the size of those seen in Colorado. A. versicolor is olivaceous yellow with touches of dull red. A. vitellina, pure yellow, as in Colorado and Southern California." 


\section{Collectors of nivicolous myxomycetes in western mountains, U.S.A.}

These collectors are highlighted in Figure 2 represented by the photograph of their field collection data on box labels.

C.J. Alexopoulos was a distinguished mycologist who published his research on myxomycetes and fungi throughout his professional career. Although his high elevation collections were not cited in his myxomycete publications, collections of Arcyria versicolor cited here were from high elevation sites in Nevada, Oregon, Washington, and Wyoming. His collections were transferred from the University of Texas to the U.S. National Fungus Collections (BPI) and are available on loan.

W.B. Cooke was a prolific collector of fungi and myxomycetes especially the nivicolous myxomycetes of Mount Shasta, California. He spent the summers as custodian of Shasta Alpine Lodge collecting on Mount Shasta, the second tallest mountain peak in the Cascades at 4,322 $\mathrm{m}$. His five collections of Arcyria versicolor from Mount Shasta were in late June and July. Most of his myxomycete collections were sent to G.W. Martin at the University of Iowa and are now available on loan from BPI.

D.T. Kowalski was the first mycologist to concentrate on nivicolous myxomycetes in the far western coastal states, especially the Sierra Nevada Mountains of California. Some of his collections were deposited at the University of Michigan (LSA), others in the University of Iowa myxomycete collection (now located at BPI), over many years of correspondence with G. W. Martin, and still others at the Chico State University Herbarium (CHSC) where many of his type specimens and nivicolous myxomycete species from northern California are located. Kowalski (1967) comments on his observations on nivicolous myxomycetes: "The great majority of montane myxomycetes are found only near the melting snow, but, if no rain has fallen, they may be found a few hundred yards from any snow banks. It appears that most species actually form their fruiting bodies under the snow and that as the snow melts back, they are then exposed. This belief is based on the fact that the discovery of plasmodia in the mountains is very rare."

T.H. Macbride's travels to collect myxomycetes in New Mexico resulted in a publication that documented myxomycetes from the Sacramento Mountains (Macbride 1905). The list of 25 common myxomycete species appears collected in August-September during the rainy season. None are nivicolous myxomycete species.

D.H. "Sam" Mitchel's life story was highlighted as a special article in FUNGI (Evenson et al. 2018). His passion for mushrooms and myxomycetes resulted in the discovery of species new to science and numerous collections of Arcyria versicolor (41 some jointly with Chapman) cited here under collections recorded. Sam Mitchel and HWK share the same home state of Kansas in small rural towns, the former at Winchester in northeastern Kansas and the latter in the Flint Hills of central Kansas at Peabody. However, Sam was a brilliant student who was offered a scholarship to Harvard University Medical School graduating cum laude and then served in World War II as a medical doctor with the rank of major in the Pacific theater. Sam and Shirley Chapman collaborated together collecting more than 9,000 myxomycete specimens in high elevation areas of Colorado (Evenson et al. 2018). Most of his collecting was in the montane and subalpine life zones located in central Colorado usually between 2,150 and 3,500 m at timberline. Many of these myxomycete specimens were deposited at BPI where M.L. Farr also worked and who published together as a myxomycete authority with Sam. The majority of his myxomycete collections are deposited at DBG, and are available on loan. The combined Kathryn Kalmbach Herbarium and Sam Mitchel Herbarium of Fungi are part of the Natural History Collections at the Denver Botanic Garden.

\section{What are nivicolous myxomycetes?}

Nivicolous (snow-loving) myxomycetes are a special ecological group that occur in mountainous terrain at the snowline or underneath along the margins of melting snowbanks (Fig. 1F). Fruiting occurs during spring in North America, typically, from April into June, and at the highest elevations sometimes July in forested areas. This distinct group includes genera mostly in the dark-spored orders Physarales and Stemonitales. These species survive when the snowpack reaches a depth of 0.5 to $2 \mathrm{~m}$ that allows for the formation of a subnivean zone. This zone forms when latent heat from the ground melts and forms a thin layer of air insulated by the proper snow depth that maintains temperatures near freezing. Under these conditions the plasmodium is able to feed on the plethora of microbes also living in the soil surface space and survive the subfreezing air temperatures at night. During springtime air temperatures rise during the day, sometimes reaching $30^{\circ} \mathrm{C}$, causing the snowpack to melt. These conditions occur as the myxomycete plasmodium feeds and grows until eventually forming large numbers of fruiting bodies, in some cases covering extensive areas of several meters and often with 
different Lamproderma species. Observation of the life cycle resting stages capable of overwintering, such as the sclerotium, microcysts, or germinating spores still remains largely understudied.

\section{Observations of nivicolous myxomycetes}

New Mexico provides numerous mountainous areas that receive winter snows that often provide growth conditions for nivicolous myxomycete species. At least $30 \mathrm{~cm}$ of snow is required (RLP, pers. obs.) to assure conditions maintain above freezing temperatures at the soil surface and below the snow interface (subnivean zone) so that organisms such as other protozoans, bacteria, fungi, and algae continue to survive under these conditions and provide food sources for myxomycete amoeboflagellates and plasmodial development which continue to thrive.

It is not surprising that the soil microbiome has been recognized as the most diverse microbial ecosystem. Soils that produce large populations of nivicolous myxomycetes have been analyzed for the presence of myxomycete amoeboflagellates and plasmodia (Dahl et.al. 2018). A four-year survey revealed a coherent pattern between occurrence of fruit bodies and soil amoebae populations for nivicolous myxomycetes (Dahl et al. 2018). It has been speculated that the myxomycete soil component makes up a very large but unquantified portion of studied soil.

Personal field observations (RLP) for the production of numerous nivicolous fruiting colonies include: (1) at least $30 \mathrm{~cm}$ of snow cover throughout the winter months which preserves above freezing temperatures and a biologically active subnivean layer, (2) consistently warming spring temperatures with little or no frost and (3) little or no additional precipitation during the period of snow melt that may damage or interrupt sporangial formation.

Conditions that RLP has observed to be most damaging in the development of nivicolous myxomycetes in these study areas included: (1) severe to extreme periods of extended drought, (2) freezing conditions before the establishment of an adequate snow cover for the development of the subnivean layer, (3) snow, hail or rain during and following snow melt and subsequent production of sporangia, and (4) severe wind during plasmodial exposure causing premature drying of the plasmodium and/or physical damage to the fruiting structures.

Collectors of nivicolous myxomycetes in western mountains, U.S.A. record only one species of Arcyria, A. versicolor, in publications and specimens deposited in herbaria. Marianne Meyer, a world authority on nivicolous myxomycetes, who has collected and studied nivicolous myxomycetes every year since 1979 in the French Alps, communicates that Arcyria versicolor is the only nivicolous species of Arcyria occurring in the French Alps at high elevations (Meyer, pers. obs.) based on 83 collections.

Observations and collection of nivicolous myxomycetes in the Sandia and Jemez Mountains by HWK and RLP resulted in noteworthy areas of several meters covered with fruiting bodies of Lamproderma sauteri Rost. and Physarum albescens Ellis ex T. Macbr, the former in the dark-spored Stemonitales and the latter in the darkspored Physarales.

The aphanoplasmodium type produced by species of Lamproderma and Comatricha and the phaneroplasmodium type produced by species of Lepidoderma and Physarum typically form large plasmodia capable of migrating over longer distances. This accounts in part for their final position on rocks, soil, stems of herbaceous plants and trunks of trees often several meters above ground level. In contrast, the trichiaceous plasmodium type does not typically form large plasmodia and does not migrate over long distances, and therefore, is more often found on ground level sites and decaying wood or litter (HWK, pers. obs.).

\section{Colors in the genus Arcyria}

Vivid bright conspicuous sporangial colors (red, yellow, grey, and white) with brightly colored elastic, expanding capillitial threads, characterize most of the 54 accepted species of Arcyria, (Lado 2005-2020). The capillitial threads and spore mass represent the light-spored myxomycete order Trichiales and family Trichiaceae. Examples of wide variation of sporangial and capillitial colors are perhaps more conspicuous in Arcyria than for any myxomycete taxon. The peridium usually disappears early leaving behind a basal disc, or more often a cup called a calyculus, of varying sizes. The combination of bright colors, a fragile evanescent peridium, 
branching and anastomosing capillitial threads forming elastic plumes that extend much beyond the length of the sporangium, similar to cotton candy, often catches the eye of collectors in the field. Many species of Arcyria form stalked sporangia and cover extensive areas on rotting logs on ground sites but rarely on decaying leaves on ground litter.

Sporangia exposed to weather elements in the field may fade losing their bright colors due to sun-bleaching over time. Similarly, fading also occurs in herbarium specimens. A good example is Arcyria denudata that forms stalked sporangia that may cover several square meters on well decayed logs. On one occasion at the Fort Worth Nature Center and Refuge in an area where the city of Fort Worth had piled dead tree logs, sometimes 3 to $6 \mathrm{~m}$ high, myxomycetes were abundant after heavy rains for several days (HWK, pers. obs.). Crowded stalked fruiting bodies of $A$. denudata covered an area of several square meters partially exposed on the surface of wood in a sun field with dirty brown colored sporangia, in contrast to protected darkness (partially under a flap of bark) that had separated from the wood, where sporangia were bright red colors. Colors similarly may vary when sporangia develop under different environmental conditions of temperature and after rainy periods and sunny days often causing premature drying (Fig. 4A). Fruiting bodies are often brightly and conspicuously colored especially for many species in the Trichiaceae because premature drying retains the brighter colors of the plasmodium, and as a result, the fruiting body hardens and the internal structures (spores and capillitial threads) are aberrant (Fig. 4A). Therefore, collectors should avoid these fruiting bodies in the field (Keller et al. 2017).

Arcyria versicolor, as the name implies, has variable colors aptly described by Duane "Sam" Mitchel who collected myxomycetes in Colorado along with fungi for more than 25 years (Evenson et al. 2018). His collecting activity was concentrated in the state of Colorado mostly in Gilpin, Grand, and San Juan counties, but also included Archuleta, Clear Creek, Eagle, Gunnison, Mineral, and Summit. Collections came from the montane and subalpine life zones of the mountains of central Colorado between 2,150 and 3,500 m. during springtime and early snow melt of April, May, and June intermittently through November (Evenson et al. 2018; Mitchel et al. 1980). Photographic images from collections found especially in the French Alps (Meyer, pers. obs.) and Russia (Novozhilov, pers. obs.) also show this range of color variation but mostly are confined to the capillitial threads not the calyculus (Fig. 3F).

\section{Transitional color changes from plasmodium to fruiting body stage}

Collectors tend to gravitate to productive habitats when favorable environmental conditions increase the chances that myxomycete fruiting bodies will be present. This usually involves seasonal temperatures and rainfall which will produce the greatest myxomycete species biodiversity. The nivicolous myxomycetes in the western mountains U.S.A. usually are found in the springtime months of April to July, depending upon the amount of winter snowfall, elevation, and day and night temperatures as the snow melts. In contrast, the corticolous myxomycetes in the midwestern and southeastern U.S.A. states are found during the months of June, July, and August, and less frequently in September, when daytime temperatures are $27^{\circ} \mathrm{C}$ to $38^{\circ} \mathrm{C}$ and nighttime temperatures stay above $21^{\circ} \mathrm{C}$. These conditions must be combined with adequate rainfall over several days along with cloudy conditions that prolong the chances for plasmodia to grow and develop into fruiting bodies. Most collecting field trips are planned to coincide with these conditions but are limited in time and space and the good fortune of being in the right place at the right time. Few collectors observe and concentrate their collecting activity on a daily or several-day basis over longer periods of time such as months. This sometimes results in fruiting bodies that undergo color changes over time that are not included in species descriptions. Badhamia rugulosa T.E. Brooks \& H.W. Keller (Keller \& Brooks 1975) in the Physarales: Physaraceae, is one example that has a calcareous peridium and capillitial calcareous nodes which undergo color changes over time when observed in the field over a several-month period.

Arcyria versicolor has striking and variable color changes from the plasmodial stage to the fruiting body stage (Figs. 3A-F). Although the plasmodial stage is seldom seen in the field and in most monographs is cited as plasmodium? (Hagelstein 1944) or unknown (Martin \& Alexopoulos 1969), the observations of Mitchel et al. (1980) are especially important p. 318: "This montane species is the most abundant Arcyria in the Colorado 
Rockies. Fruitings often exceed $20 \mathrm{~cm}$ in diameter or may completely encircle a rotten spruce stump. The color may vary in one collection from dull red through many shades of greenish-yellow, yellow, gold and orange. Other collections are uniformly brilliant canary yellow. Color is the only variable character. The plasmodium, not described in most texts, is white at first, changes to salmon-egg red to coral pink and finally yellow before fruiting." This quotation accurately describes the transitional changes prior to and during fruiting body formation.

The gradation of spore development from larger, thinner walled pre-spore initials at the stalk bottom to the more mature smaller spore-like bodies at the top of the stalk (Fig. 4C) eventually merge into mature spores in the spore case intermingled with the capillitium (Fig. 4D). This developmental sequence suggests the stalk spore-like bodies would be capable of germination but according to Mims and Rogers (1975) these spore-like bodies never germinate.

\section{Nomenclatural history of Arcyria versicolor}

The names Arcyria vitellina and Arcyria versicolor were both validly published as new species in 1877 appearing on the same page 115, the former first in position and the latter second with the species description in English (Phillips 1877). There is unanimity among myxomycete monographers that the two are the same species, therefore, one must be considered a synonym of the other. A review of the past monographic myxomycete literature will document the treatment of these two Arcyria species. The British authors, George Massee (1892) and the Listers, Arthur and Gulielma $(1894,1911,1925)$, all used the name A. versicolor and considered A. vitellina a synonym. No reason was given for their acceptance of this name.

Macbride (1899) and Sturgis (1907) accepted the name A. vitellina and relegated A. versicolor to synonymy. Macbride (1922) accepted the name A. versicolor but gave no explanation for the name change. Macbride and Martin (1934) retained the name A. versicolor, justifying this with the following words "While the name vitellina has priority of position, both Massee and Lister, in uniting the two species, preferred the second name, and it may be regarded as established."

Sturgis (1907) recognized the name A. vitellina because "... the law of priority compels the use of ..." A. vitellina. Robert Hagelstein (1944), who was an avid collector in the eastern states of the U.S.A., studied myxomycetes at the NYBG. He recognized the name A. vitellina, emphasizing priority of first position saying “... it must be accepted as the name under present rules of nomenclature."

Martin (1949) and Martin and Alexopoulos (1969) simply accepted the name A. versicolor, without any additional comments. Marie Farr 1976) accepted the name A. versicolor and indicated the type as Phillips 362 and paratypes as Phillips 379 and 440, with the same collection dates. These collection numbers were cited by Phillips (1877) in his publication.

Carlos Lado and Francisco Pando (1997) in their Flora Mycologica Iberica provide beautiful line drawing illustrations of Arcyria versicolor and the most detailed species description to date. They designated Phillips collection 362 as the type and Phillips 379 and 440 as the lectotype and cite Farr (1976) as the literature source.

What is the status of these two names today based on the different versions of the Botanical Code? Arcyria versicolor should be accepted as the name of choice since priority is based on the publication of the printed word only, not the position of the name, and since both species occur on the same page in the same publication, Arcyria versicolor is a better descriptive name since it reflects the variable sporangial colors (Figs. 3A-F).

\section{TAXONOMIC TREATMENT}

\section{Arcyria versicolor W. Phillips (Figs. 3A-F; Figs, 4A-H; Fig. 5; Figs. 6A, B; Figs. 7A, B; Figs. 8A, B; Figs. 9A, B). Grevillea 5(35):115. 1877.}

Sporangia gregarious, crowded, or tightly clustered, often in large groups, distinctly or weakly stalked, sometimes nearly sessile, total height (1)2-6(8) mm, width 1-2 mm, before dehiscence, after expansion of capillitium up to $10 \mathrm{~mm}$ in height; capillitium bright canary yellow, olivaceous, sometimes scarlet, reddish hues to dirty brown in weathered specimens, arising from a deep funnel or vase-shaped calyculus (cup), often retaining preformed sporangial shape; peridium apically membranous, evanescent, either dehiscent by a 


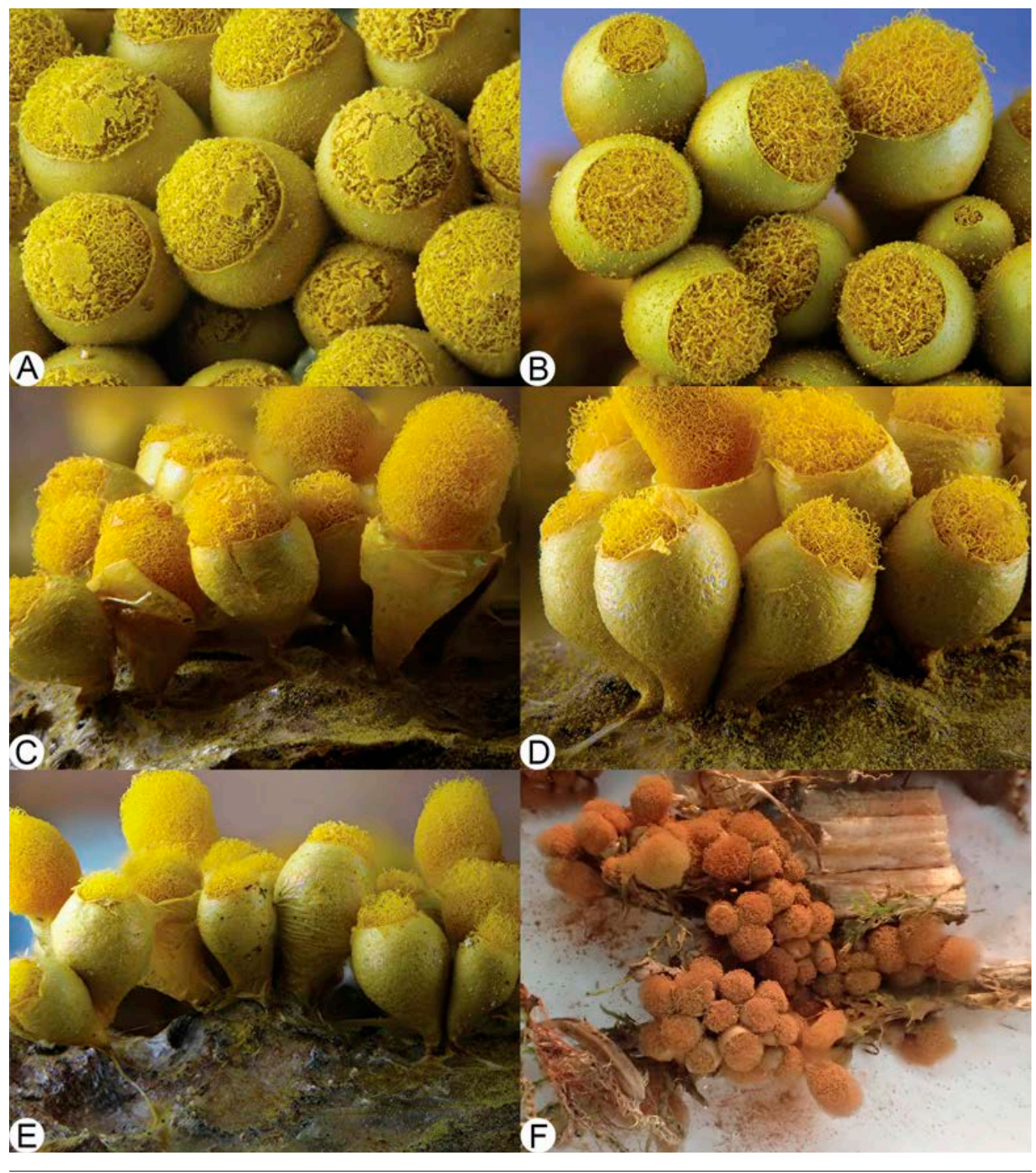

FIG. 3 A-F. Arcyria versicolor habit images. A. Top view of canary yellow sporangium showing apical membranous remnants adhering to underlying capillitium. Note circumscissile circular dehiscence with sharp edges delimiting the opening beginning to expose the capillitial mass. B. Sporangia with top view highlighting various circular openings with initial expansion of capillitial mass upper right. C. Profile view showing funnel-shaped nearly sessile sporangia. Note capillitium expanding above the peridium retaining sporangial shape of calyculus. Membranous hypothallus at base in foreground with bright yellow spores. D. Cluster of sessile sporangia in side view showing two different dehiscence patterns: splitting open with torn jagged margins (middle foreground) and circular sharp edges (right side). E. Sporangia side view in various stages of dehiscence. Capillitial mass of expanding threads retaining sporangial shape. F. Marianne Meyer specimen \#45763 collected from French Alps. Note reddish elastic capillitial threads expanded in plumes above calyculus. 


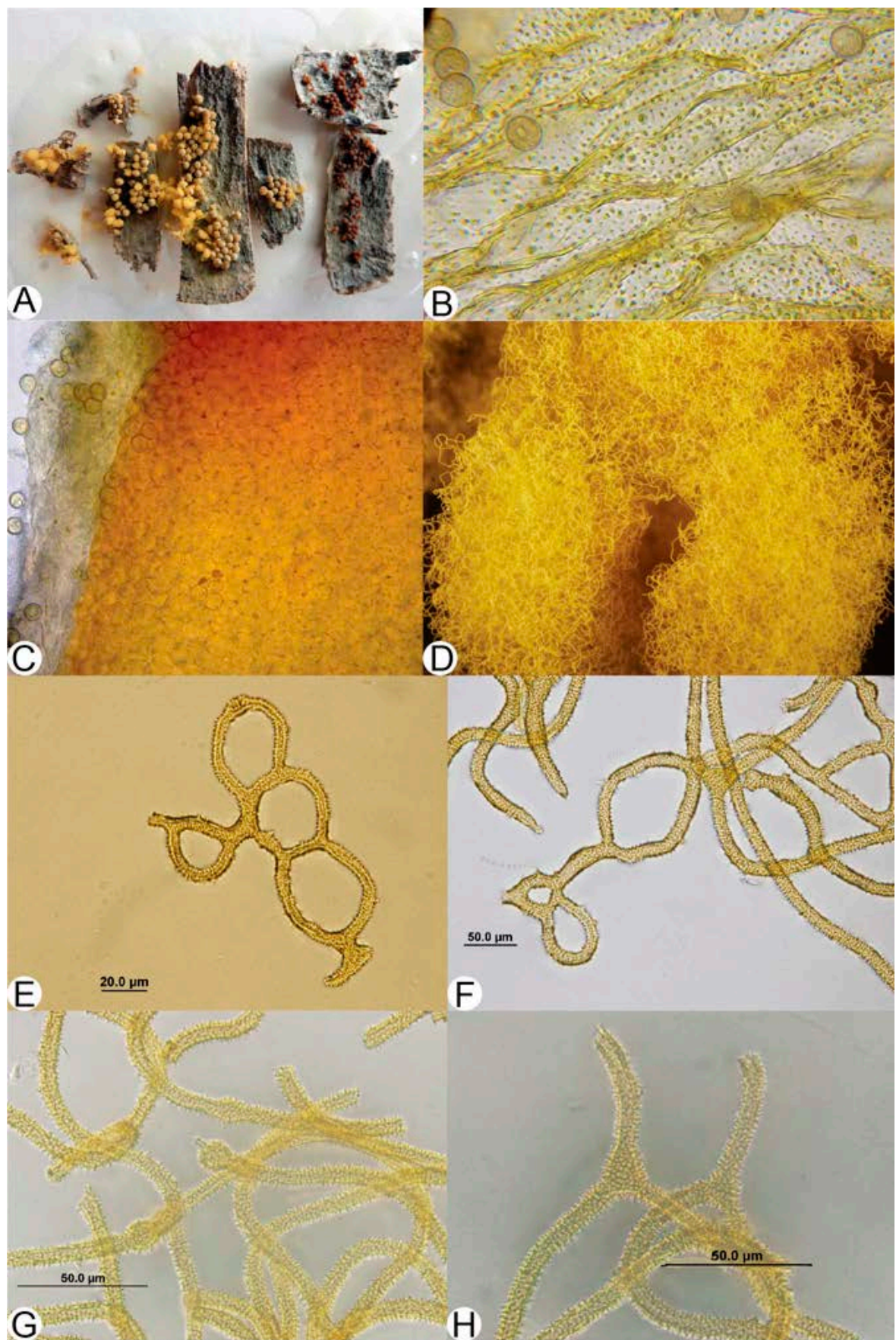

FIG. 4 A-H. Arcyria versicolor light microscopic photographic images. A. Premature aborted sporangia on the far right; immature and mature dehisced sporangia middle, mature dehisced sporangia far left. B. Conspicuous ornamentation on inner surface of peridium with scattered thin-walled pale spores. C. Portion of stalk with larger spore-like bodies on right and thin-walled smaller spores on left. D. Entangled mass of branching and anastomosing bright yellow capillitial threads. Capillitial threads stay together in mass because interconnections do not fragment. E. Capillitium forming rings. F. Capillitial interconnections and conspicuous spinulose ornamentation. G. Capillitial threads with swollen free end, hollow lumen (middle) and intercalary swelling (left) conspicuously spinulose. H. Capillitial threads broken ends showing hollow lumen, tripartite branching, and conspicuous spinulose ornamentation. 


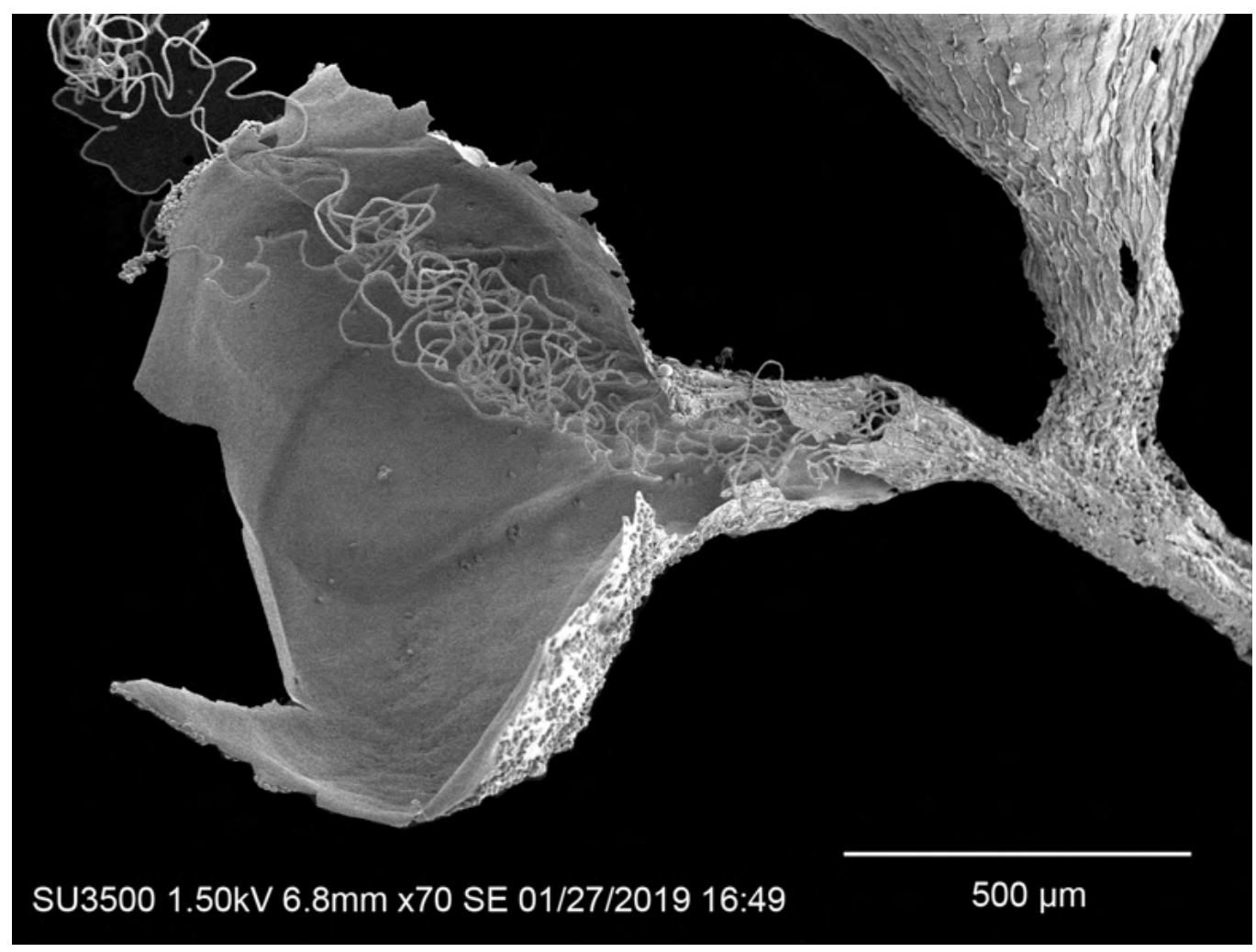

FIG. 5. Arcyria versicolor lower magnification SEM. Two fused striated stalks. Note long coiled capillitial threads arising from basal sporangial attachment. Outer peridial surface roughened with granular markings with long unbroken coiled threads inside funnel shaped calyculus.

circumscissile circular sharp-edged area or fragmented with jagged edges, persisting as a shiny to dull deep cup below; peridial outer surface striated with scattered granules, inner surface marked with conspicuous papillae; stalk cylindrical erect often filled with spore-like bodies; hypothallus when present, thin, membranous common to groups of sporangia, sometimes inconspicuous or lacking; capillitium a dense branching and anastomosing network of loosely entangled threads, attached at a single basal point, expanding above as an elastic network plume, concolorous, long branching threads with loops, infrequent terminal and intercalary swellings with few free ends, threads 5-6-(9) $\mu \mathrm{m}$ in diameter, tubular, hollow, conspicuous surface ornamentation evenly surrounding threads, of broken reticulations, rounded or peg-like protuberances intermixed with spinules; spores in mass, usually bright yellow, occasionally reddish hues, by transmitted light pale, wall thin uniformly marked with short blunt projections sometimes including scattered patchy aggregates, 10-11 $\mu \mathrm{m}$ in diameter. Plasmodium yellow, pink to reddish.

Etymology.-Arcyria-From the Greek öpкvऽ = arcy=net). The generic name aptly describes the elastic, netted capillitium that expands into plumes either attached or free above a calyculus (cup) of various shapes and sizes, deep or shallow, and in some species reduced to a basal disc. The upper part of the peridium is evanescent early and in most species forms a brightly colored network of capillitial threads and a spore mass predominantly of yellows or reddish hues. The species epithet: versicolor = various colors, multicolored, shiny variable colors referring to the yellow or rosy to red colors in freshly formed sporangia.

Type locality.-William Phillips was the author (1877) of Arcyria versicolor a species new to science published in Grevillea. However, Dr. H.W. Harkness and J.P. Moor were the collectors of the specimens and 

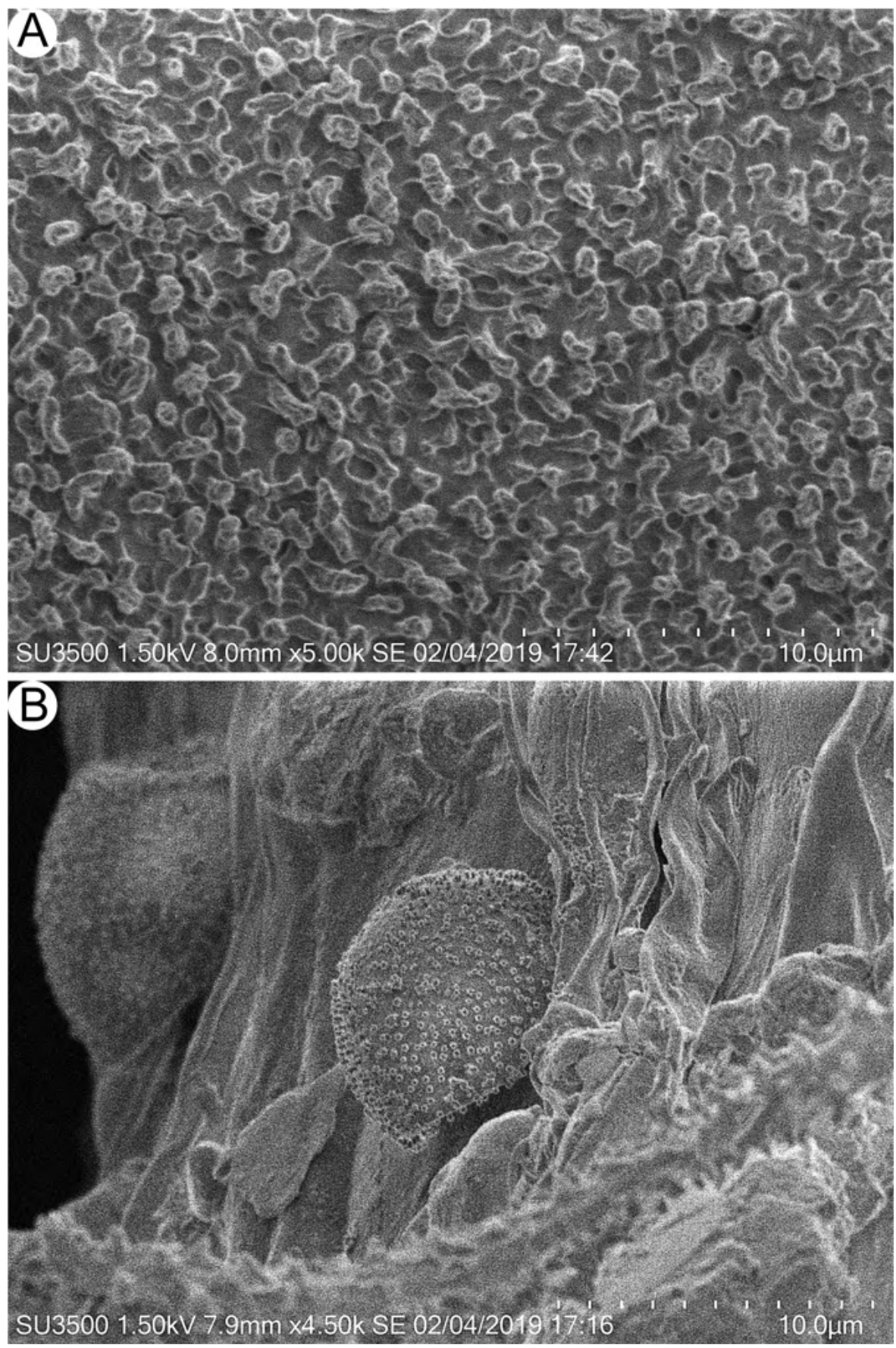

FIG. 6. A. SEMs. Inner peridial surface with scattered crater-like depressions and conspicuous short projections deemed papillae. B. Spore ornamentation of blunt projections sometimes several fused. 

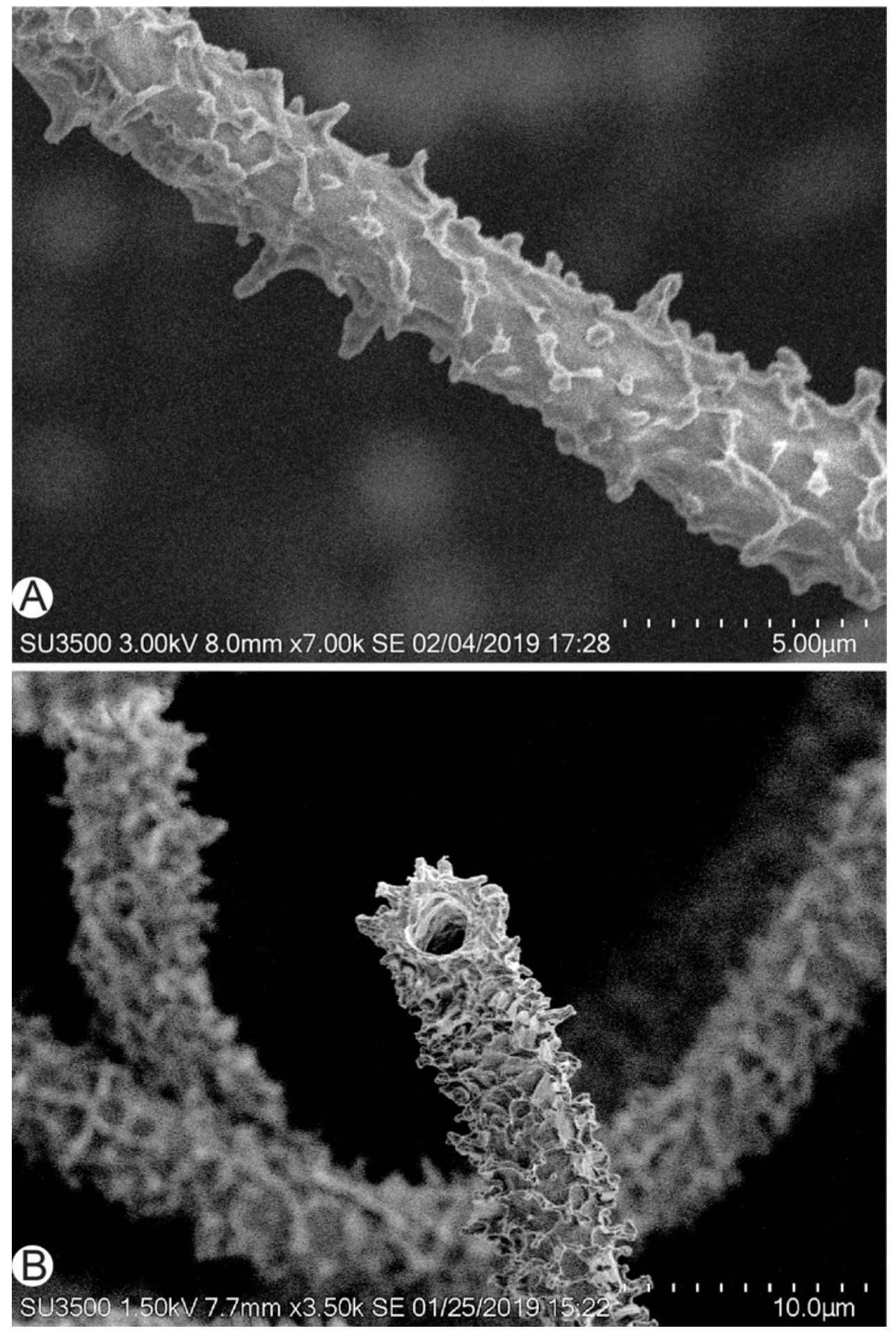

FiG. 7. SEMs of capillitium. A. Thread segment with broken reticulations intermixed with blunt spinules and knob-like bodies. B. Thread segment showing broken end with hollow interior. Note surface ornamentation of broken reticulations and short spinules. 
recorded the site as Sierra Nevada Mountains, Blue Canon, on the line of the Central Pacific Railway at an elevation of 4688 feet ( $1432 \mathrm{~m}$ ) above sea level. Blue Canon in Spanish is given the tilde, Cañon, to emphasize the pronunciation and was the name for an unincorporated village at the time of the collection. This area also goes by the name of Blue Canyon, including Canyon Lake. Most states in the U.S.A. use counties as political subdivisions and herbarium specimens are usually recorded by counties. It appears that this was a nivicolous collection near early springtime snowbanks (April) in Placer County, California.

Distribution.-Worldwide, typically in high elevation mountainous regions. Argentina, Australia, Austria, Canada, France, Germany, Italy, Japan, Morocco, Russia, Spain, Turkey. Arcyria versicolor records have not been published for any of the Scandinavian countries (Eliasson, pers. obs.). U.S.A. Mountainous states, California, Colorado, Idaho, Nevada, New York, Oregon, Utah, Washington, Wyoming. Reported from Colorado by Sturgis in 1907, p. 41 (3 1) as A. vitellina Phill. from collections made in Gilpin, Grand and San Juan counties.

Habitat.-High elevation melting snowbanks usually on ground litter of decaying coniferous wood. Type collection on Pinus contorta Douglas (Lodgepole Pine).

Seasonality.-April to June in mountainous areas of North America. The majority of the collections of Arcyria versicolor from New Mexico and Colorado occur during months of May and June a few occur in July.

Iconography/lllustrations. - Lister, 1925. A monograph of the Mycetozoa, p. 175 a-1c, b/w. Macbride \& Martin, 1934. Pl. XVII. 456, 457, b \& w. Martin \& Alexopoulos, 1969. The myxomycetes. Pl. IX, 95 a-c, color, p. 496,497. Emoto, 1977. Myxomycetes of Japan, Figs. 6-10, p. 58, 59 (Figs. 6, 7 shape and color are wrong). Neubert, Nowotny, \& Baumann, 1993. p. 195, (196 color). Lado \& Pando, 1997. Fl. Mycol. Iber. vol. 2. Fig. 58 a-le, excellent line drawings, p.196. Poulain, Meyer, \& Bozonnet, 2011. Les Myxomycetes. Vol. 2, p. 104 a-1c.

Terminology.-Myxomycete terms used in this species description and throughout this paper follow Keller et al. (2017).

\section{Collections Recorded.-Arcyria versicolor at BPI.}

U.S.A. CALIFORNIA. Fresno Co.: Huntington Lake, Jun 1949, Mary S, Gibbons 186290 (MGB), 833841 (BPI). Lassen Co.: Lassen Volcanic National Park, 2 Jul 1965, H. Thiers 14866, 833817 (BPI). Mariposa Co.: 6 Jun 1950, Clarence R. Quick 50B, 833837 (BPI). Mendocino Co.: Mendocino, 22 Feb 1965, on humus or litter in mixed forest, H. Thiers 14,852, 833816 (BPI). Nevada Co.: Donner Lake, 7 May 1934, on rotting wood, E.E. Morse 883715 (BPI). San Bernardino Co.: Big Bear Lake, O. A. Plunkett 833838 (BPI). Siskiyou Co.: Mount Shasta, 2438 m, 25 Jun 1946, W.B. Cooke 18062, 833835 (BPI); Mount Shasta, on Abies magnifica shastensis, 25 Jun 1948, W.B. Cooke 18063, 833836 (BPI); Mount Shasta, 1524 m, 6 Jun 1938, W.B. Cooke 10245, 833844 (BPI); Mount Shasta, 2591 m, 28 Jul 1938, W.B. Cooke 10245, 833845 (BPI); Mount Shasta, 2591 m, 28 Jul 1938, W.B. Cooke 10245, 833845 (BPI); Mount Shasta, Panther Meadow Campground, 2316 m, D.T. Kowalski 1867, 833839 (BPI); Mount Shasta, 25 Jun 1966, D.T. Kowalski 3732, 833849 (BPI); Mount Shasta, 2438 m, 27 Sep 1947, W.B. Cooke 20197, 833840 (BPI). Tehama Co.: 5 mi E of Mineral, on decayed wood, 15 May 1966, D.T. Kowalski 3004, 833850 (BPI); 4 mi S of Lassen National Park, on decayed wood, 22 May 1965, D.T. Kowalski 1336, 833851 (BPI). Tulare Co.: Sequoia National Park, Dorst Campground, 17 May 1981, F. Nishida 251278 (LAM), 883697 (BPI); Sequoia National Forest, Homer's Nose, 11 Jul 1987, W.R. Dudley1896, 333848 (BPI); Harkness 26, s.n. 833846 (BPI); T.H. Macbride s.n. 833859 (BPI); Wingate Collection, J.B. Ellis, s.n. 833860 (BPI); Yosemite, 1905, T.H. Macbride s.n. 833868 (BPI). COLORADO. Clear Creek Co.: Squaw Pass, 4-mile, snowbank, 4 Jun 1980, S.W. Chapman 833928 (BPI); E Side Berthoud Pass, Hoop Creek, snowbank, 24 Jun 1984, S.W. Chapman 833935 (BPI); E Side of Loveland Pass, snowbank, 30 Jun 1982, S.W. Chapman 833943 (BPI). Eagle Co.: Tenderwild Springs, 3 May 1981, Mitchel 833920 (BPI); Middle Lake, park above Dead Dog Pass, 21 Jun 1980, Mitchel 833919 (BPI); Mitchel Ranch, 12 Jun 1982, Mitchel 833925 (BPI); W slope Dead Dog Pass, 2 Jun 1979, Mitchel 833926 (BPI); Snowslide Park, 21 Jul 1979, Mitchel 83394 (BPI); Mitchel Ranch, snowbank, 5 Aug 1982, Mitchel, no BPI bar code number; ?will Lake, 26 May 1979 , Mitchel 833942. Grand Co.: Berthoud Pass, 3,444 m, snowbank, 9 Jul 1978, S.W. Chapman 833929 (BPI). Gunnison Co.: Gothic Campground, 25 Jul 1970, S.W. Chapman 833827 (BPI); Gothic Campground, 25 Jul 1970, S.W. Chapman 833939 (BPI). Mineral Co.: W side of Wolf Creek Pass, snowbank, 22 Jun 1973, S.W. Chapman 833946 (BPI); Wolf Creek Road \#139, Mineral City, 3,200 m 29 Jul 1981, Iris R. Nelson 833918 (BPI). Summit Co.: forest above S end QCV Ranch, 18 Jun 1976, S.W. Chapman 833868 (BPI); VA-CV Ranch, sawmill, 3 Jun 1977, S.W. Chapman 833924 (BPI); VQ-CV Ranch, Spring Creek, snowbank, 20 May 1978, S.W. Chapman 833927 (BPI); V Q-C-V Ranch, NW of cabin on blue spruce bark, 5 Aug, 1976, S.W. Chapman 833940 (BPI); Rocky Mountain National Park, 3,414 m, 7 Jul 1960, J. \& M. Douglass 833826 (BPI). IDAHO. 31 Aug 1911, J. Macbride 833879 (BPI). IOWA? Macbride 13, 338822 (BPI). NEVADA. Duchesne Co.: 8 Aug 1963, Mary V. Dublin 2231, 896003 (BPI). Linn Co.: Lost Prairie Campground East Tombstone Pass Route US 20, 982 m, 11 May 1968, C.J. Alexopoulos 833852 (BPI); during MSA Ascomycete Workshop, Waldo Lake, on bark and rotten wood by lakeshore, 13 Aug 1975. M.L. Farr, 833853 (BPI. Washoe Co.: Galena Creek, 16 May 1952, Robert Bandoni 3, 833821 (BPI). NEW YORK. Rockland Co.: Sparkill, 10 Aug 1904, G.A. Reichling 833820 BPI). OREGON. Benton Co.: Mary's Peak, 1,219 m, 11 May 1968, C.J. Alexopoulos 833855 (BPI). Klamath Co.: Crater Lake National Park, 2,073 m, 18 Jul 1967, D.H. Curtis 833832 (BPI); Cascade Mountains, H.C. Gilbert 100. UTAH. Duchesne Co.: 8 Aug 1963, Mary V. 
Dublin 2231, 896003 (BPI). Summit Co.: Mill Creek, on bark of conifer stump off transect, stand 2, Wasatch National Forest, 26 May 1971 , K.H. McKnight 12105, 833829 (BPI); Mill Creek, on soil by burned wood, 1 Jun 1970, K.H, McKnight \& L.B. McKnight 11791, 833830 (BPI); 21 Jun 1952, McKnight F253, 895999 BPI); 9 Aug 1963, Mary V. Dublin 2254, 896042 (BPI). Utah Co.: 16 Jul 1955, K.H. McKnight \& R. Duke 895995 (BPI); 26 Jul 1949, K.H. McKnight 833823 (BPI). WASHINGTON. Clallam Co.: Olympic National Park, Hurricane Ridge, 732 m, 30 Nov 1965, Meredith Blackwell \& C.J. Alexopoulos, 833825 (BPI); Kittitas Co.: Keechelus Ridge, 4 Jul 1974, Stowell 1351, 833815 (BPI); Hurricane Ridge, 1585 m, Olympic National Park, on twigs, 25 Jun 1968, D.T. Kowalski 9362, 835826 (BPI). Pierce Co.: Mt. Rainier, Paradise Valley, 1636 m, 8 Aug 1970, C.J. E Juliet Alexopoulos 833825 (BPI); Mount Rainier, Indian Henry, T.H. Macbride 833880 (BPI). Whatcom Co.: Mt. Baker, 26 Jul 1974, Stowell 1420, 833814 (BPI); N End Drive Campground, 14 Jun 1964, J.L. Maas 2274, 833881 (BPI). WYOMING. Albany Co.: Little Brooklyn Lake, 7 Aug 1950. C.J. Alexopoulos E E.S. Beneke, 833818 (BPI); Fox Park, on Pinus contorta, 12 Jul 1917 , V. Simmong 833819 (BPI). Carbon Co.: Brush Creek Campground, 10 Jun 1971, John Baxter 833937 (BPI). Teton Co.: Grand Teton National Park, University of Wyoming National Park Service Research Center, on pine stump, 29 Jun 1979, K.H. McKnight 16529, from Brigham Young University, Provo, Utah, 894499 (BPI). Total number of collections 73.

\section{Arcyria versicolor collections at Denver Botanical Garden (DBG).}

U.S.A. COLORADO. Boulder Co.: swampy area near Lost Lake near Hesse, 2993 m, 27 Jul 1978, Vera S. Evenson, DBG-F-007936; Alex Dawson Ranch, no data, 30 Jun 1980, Vera S. Evenson, DBG-F-007989. Clear Creek Co.: Guanella Pass, Lost Lake, 3528 m, 7 Jun 1980, D.L. Plastino, DBG-F-010676; Squaw Pass, six mile, snowbank, 2876 m, 16 Jun 1980, Shirley Chapman, DBG-F-010802. Eagle Co.: Mitchel Ranch, snowbank, 2712 m, 10 May 1986, Duane H. "Sam” Mitchel, DBG-F-015808; Mitchel Ranch, moist rotten log, E bank stream, 2712 m, 2 Sep1972, Duane H. "Sam” Mitchel, DBG-F-003341; Mitchel Ranch, top of hill, no data, 21 Jul 1973, Duane H. "Sam” Mitchel, DBG-F-003923; White River National Forest, N slope snow slide ridge, Middle Lake trail, 2846 m, 5 Jul 1975, Duane H. "Sam” Mitchel, DBG-F-005824; White River National Forest, N slope snow slide ridge peak, 2950 m, 4 Jul 1975, Duane H. "Sam” Mitchel, DBG-F-005827; White River National Forest, N slope snow slide ridge peak, 2950 m, 4Jul 1975, Duane H. "Sam" Mitchel, DBG-F-005828; Tenderwild - spring, no data, 9 May 1976, Duane H. "Sam" Mitchel, DBG-F-006558; Murphy Creek, Barida cabin road, 3131 m, 12 Jun 1976, DBG-F-006762; Tenderwild, no data, 14 May 1978, Duane H. "Sam” Mitchel, DBG-F-008900; Tenderwild Lake, no data, 26 May 1979, Duane H. "Sam” Mitchel, DBG-F-009578. Grand Co.: Routt National Forest, Blacktail campground, Gore Pass, 2975 m, 12 Jun 1971, Rosa-Lee Brace, DBG-F-002928; Arapaho National Forest, logging road to Ptarmigan Peak, E of Church’s Park, 3627 m, 21 Jun 1975, Duane H. "Sam" Mitchel, DBG-F-005742; E edge of Church's Park, no data, 17 Jun 1978, Shirley Chapman, DBG-F-008827. Latimer Co.: Rocky Mountain National Park, Mill Creek Basin, found on conifer log near a snowbank in marshy area $\mathrm{N}$ of trail to Lake Helene from Bear Lake, spores yellow, 10.1 microns, capillitium with spines, cogs, 3-6.5 microns 3036 m, 24 Feb. 2012, M.J. Howell, DBG-F-022944. Mineral Co.: Wolf Creek Pass, Road 139, 3331 m, 26 Jun 1982, I.R. Nilsen, DBG-F-013144; Wolf Creek Pass, Road 139, 3331 m, 26 Jun 1982, I.R. Nilsen, DBG-F-013146; Wolf Creek, Road 139, 3331 m, 23 Jun 1982, J.R. Nilsen, DBG-F-013148; Treasure Falls, 2463 m, 22 May 1982, I.R. Nilsen, DBG-F-013151. Summit Co.: Arapaho National Forest, Quarter Circle V Ranch, 2253 m, 22 May 1971, Shirley Chapman, DBG-F-003021; Arapaho National Forest, Quarter Circle V Ranch, north fork Deep Creek, 2253 m, 20 Jun 1971, DBG-F-003044; Arapaho National Forest, forest road above Quarter Circle V Ranch, 2253 m, 4 Jul 1971, Duane H. "Sam" Mitchel, DBG-F-003060; Arapaho National Forest, road to Mayhan Lake, 3348 m, 27 Jun 1971, Shirley Chapman, DBG-F-003069; Arapaho National Forest, behind Sawmill cabin, Quarter Circle V Ranch, 2253 m, 14 August 1971, Shirley Chapman, DBGF-003072; Arapaho National Forest, Quarter Circle V Ranch, woods between cabin and Spring Creek, 2253 m, 7 May 1972, Shirley Chapman, DBG-F-003200; Arapaho National Forest, Quarter Circle V Ranch, woods between cabin and Spring Creek, 2253 m, 7 May 1972 , Shirley Chapman, DBG-F-003202; Arapaho National Forest, Quarter Circle V Ranch, NW portion of woods between cabin and Spring Creek, 2253 m, 26 May 1973, Shirley Chapman, DBG-F-003670; Arapaho National Forest, Quarter Circle V Ranch, Spring Creek, 2253 m, 4 May 1974, Shirley Chapman, DBG-F-004205; Arapaho National Forest, 3 mi from Mayhan Lake, forest above Quarter Circle V Ranch, 2253 m, 12 Jul 1974, Shirley Chapman, DBG-F-005765; Quarter Circle V Ranch, Spring Creek drainage, 2253 m, 22 May 1976, Shirley Chapman, DBG-F-006499; 1 mile up from intersection - road to Mayhan Lake, spruce and snow, no data, 5 Jun 1976, Shirley Chapman, DBG-F-006656; forest above S end Quarter Circle V Ranch, 2253 m, 19 Jun 1976, Shirley Chapman, DBG-F-006682; Quarter Circle V Ranch, N of cabin, 2253 m, 13 May 1978, Shirley Chapman, DBG-F-008599; Quarter Circle V Ranch, N of cabin, 2253 m, 14 May 1978, Shirley Chapman, DBG-F008618; Quarter Circle V Ranch, Spring Creek, 2253 m, 20 May 1978, Shirley Chapman, DBG-F-008697; Quarter Circle V Ranch, 2253 m, 20 May 1978, Shirley Chapman, DBG-F-008702; Quarter Circle V Ranch, N of cabin, 2253 m, 4 Jun 1978, Shirley Chapman, DBG-F-008796. Unknown Co.: no data, 30 Nov 1966, Rosa-Lee Brace, DBG-F-001830. Total number of collections 41

Arcyria versicolor collections at New York Botanical Garden (NYBG).

U.S.A. CALIFORNIA. Butte Co.: Jonesville, Jun 1932, H.F. Copeland 2674479 (NYBG). Fresno Co.: Huntington Lake, Jun 1949, M.S. Gibbons 2674480 (NYBG). Placer Co.: Sierra Nevada Mtns., Blue Canyon, April 1876, H.W. Harkness 26, type, 834200 (NYBG). San Bernardino Co.: San Bernardino, Jun 1876, E. Palmer 2674474 (NYBG); Big Bear Lake, 29 May 1927, O.A. Plunkett 2674481 (NYBG). Siskiyou Co.: along the Sisson Southern Trail near Mt. Shasta, 8 Jul 1938, W.B. Cooke 10193, 2674466 (NYBG); Horse Camp, Mt. Shasta, 25 Jun 1945, W.B. Cooke 2674465 (NYBG). Tehama Co.: vicinity Lassen National Park, 22 May 1965, D.T. Kowalski 1336, 2674464 (NYBG). COLORADO. Archuleta Co.: Pagosa Springs, 31 Aug 1911, collector unspecified, 2674489 (NYBG). Larimer Co.: Arrowhead 14 Jul 1905, E. Bethel 2674486 (NYBG); Arrowhead 14 Jul 1905, E. Bethel 2674487 (NYBG). Grand Co.: Rollins Pass, 14 Jul 1905, E. Bethel 2674488 (NYBG). Summit Co.: OCV Ranch between cabin and Spring Creek, 7 May 1972, C.W. Chapman 3200, 1782465 (NYBG). OREGON. Lane Co.: Three Sisters, no date recorded, M.E. Peck 2674483 (NYBG). UTAH. Beaver Co.: S side of Frisco Peak, San Francisco Mtns, 27 Jun 1993 , C.T. Rogerson 2674467 (NYBG); Cache Co.: near Joann Spring, Cache National Forest, S side of Curtis Ridge, SW of Red Spur Mt., 2 Sep 1971, 
C.T. Rogerson 2674469 (NYBG). Cache Co.: White Pine Lake, Bear River Mts, 9 Oct 1939, W.E. Rader (Rogerson 705) 2674472 (NYBG). Rich Co.: Spencer Basin, upper reaches of Big Creek, Cache Natl Forest, W of Randolph, 4 Sep 1971, C.T. Rogerson 2674468 (NYBG); Rich Co.: Near Leo Reservoir, Cache Natl Forest, Old Canyon, W of Randolph, 3 Sep 1971, C.T. Rogerson 2674470 (NYBG). Wasatch Co.: Along South Fork of Phelps Creek, tributary of Wolf Creek, Uinta Natl Forest, 27 August 1971, C.T. Rogerson 2674471 (NYBG). WASHINGTON. Pierce Co.: Indian Henry near Mr. Rainier, no date recorded, T.H. Macbride 2674473 (NYBG). Total number of collections 21.

\section{Arcyria versicolor collections in the private herbarium of Renato Cainelli.}

U.S.A. CALIFORNIA. Tulare Co.: Sequoia National Park, heavily degraded wood, 2182 m, 7 May 2008, Renato Cainelli 8050719; Wuksachi Lodge, Sequoia National Park, dead wood, 2154 m, 8 May 2008, Renato Cainelli 8050812; Wuksachi Lodge, Sequoia National Park, dead wood, 2145 m, 9 May 2008, Renato Cainelli 8050930; Generals Hwy, Sequoia National Forest, dead wood (fallen branches), 2189 m, 9 May 2008, Renato Cainelli 8050931; Montecito Sequoia Lodge, pine needles litter, 2233 m, 23 May 2009, Renato Cainelli 9052318; Montecito Sequoia Lodge, dead wood, 2233 m, 23 May 2009, Renato Cainelli 9052319; Montecito Sequoia Lodge, dead wood, 2222 m, 24 May 2009 , Renato Cainelli 9052403; Camp Round Meadow, CA-38 40928, bark of fallen tree, 1990 m, 25 Apr 2010, Renato Cainelli 10042514. San Bernardino Co.: Big Pines, Angeles Crest Hwy, dead wood, 2316 m, 16 May 2012, Renato Cainelli, 12051605. Riverside Co.: Idyllwild, Saddle Jct. Trail, dead wood, 2474 m, 2 Apr 2016, Renato Cainelli 16040209; Idyllwild, Saddle Jct. Trail, herbaceous stem, 2414 m, 28 Apr 2017, Renato Cainelli 17042801. Total number of collections 11.

\section{Taxonomic commentary}

In April of 1876, while snow was still evident, Harkness and Moor of the U.S.A. collected fungi, including myxomycetes, in the Sierra Nevada Mountains of California. Phillips (1877) published descriptions of two new species, Arcyria vitellina and Arcyria versicolor, based on the specimens sent to him by Harkness. Type specimens of $A$. vitellina and $A$. versicolor were obtained on loan by RLP from the New York Botanical Garden (NYBG 00834202 and NYBG 00834200, Figs. 8A, B; Figs. 9A, B). These specimens were examined with the mindset of a person in the late 1800s more than 144 years ago. This was a time when few myxomycetologists had experience observing and collecting myxomycetes over longer periods of time in different geographical areas. Consequently, with limited experience comparing many species of Arcyria, and limited knowledge of species concepts in myxomycetes, especially differences in color and dehiscence patterns, influenced recognition of two different species. Apparently, these habit characters unduly influenced the recognition of two new species. Therefore, specimens collected on a single field trip in the same area on the same day resulted in the recognition of two new species based on superficial structural differences. A sharp circular apical opening exposing the capillitium compared to a splitting or shredded apical opening as seen in the two type specimens were the main differences in recognizing the two new species (Figs. 3A-F; Figs. 8A, B; Figs. 9A, B). These variations, both in color and dehiscence patterns, were observed at the same time in the same specimens in many of the specimens examined in this study (Fig. 3D).

Capillitial nodules or swellings occur infrequently as intercalary or terminal structures in Arcryia versicolor (Figs. 4D-H). These swellings appear in other trichiaceous taxa such as Arcyria nodulosa Macbr., now recognized as a synonym of Arcyria ferruginea Sauter, and also in Minakatella longifila G. Lister. The latter species has intercalary swellings that are conspicuous and constant in all specimens (Keller et al. 1973). It appears that these structures develop from food vacuoles in the latter species. However, in Arcyria versicolor the swellings appear refractory but lack the obvious hollowness seen in Minakatella longifila. These swellings are so variable in trichiaceous taxa that little taxonomic consideration as a morphological character should be given unless combined with other distinct morphological characters.

Collection Arcyria versicolor barcode DBG-F-005827 is instructive. Sporangia on the far right have prematurely dried and are a different color more reddish brown (Fig. 4A). These aborted sporangia are hardened often retaining the colors of the plasmodium. The sporangia in the middle are fully mature bright canary yellow and have dehisced with the elastic capillitium expanding above the sporangium extending through an opening in the apex. The smaller group of sporangia in the upper left represent mature sporangia still in the undehisced stage (Fig. 4A). These sporangia are mature enough to show the bright yellow color typical of the mature sporangia. This uneven development of myxomycete fruiting bodies occurs when different parts of the substratum dry out at different rates over time. Collectors should avoid collecting the premature stages because the color here is different from mature fruiting bodies and the spores are aberrant and agglutinated often forming "giant spores." 
Dehiscence is variable in Arcyria versicolor. Some sporangia dehisce by a sharp circumscissile circular opening, and others appear torn open with jagged edges; both of these patterns occur in the same collection (Fig. 3D). These are striking differences but appear to be related to developmental factors. In both examples, a thin, membranous, evanescent apical area ruptures exposing the capillitial mass (Figs. 3 A-E). This tangled mass of capillitial threads may extend as a plume 3 to $6 \mathrm{~mm}$ above the calyculus (Fig. 4D) or remain tightly together retaining the funnel shape of the sporangium (Fig. 8B). In either case the base of the capillitial threads appears attached to the calyculus base (Fig. 5).

The external peridial surface is roughened with small granules, striations, and wrinkles (Fig. 5); the inner surface is uniformly roughened with conspicuous markings of dense papillae and circular craters (Fig. 6A); The hollow capillitial thread (Fig. 7B) surface is distinctly roughened with intermixed broken reticulations, rounded protuberances, and occasional spinules (Figs. 7A, B). Spore surface ornamentation is uniformly marked with peg-like blunt projections sometimes with several fused (Fig. 6B).

Spore-like bodies are found in stalks of Arcyria versicolor (Fig. 4C). These structures only occur in stalked species in the Trichiaceae, especially in species of Arcyria (15), Hemitrichia (6), and Trichia (1) (Martin \& Alexopoulos 1969; Lado \& Pando 1997). Sources of terms for these structures are cells and cysts used interchangeably, and less often, cellular vesicles by Martin and Alexopoulos (1969). Lado and Pando (1976) used the term cysts. Special studies of these stalk structures by Mims and Rogers (1975) and Rammeloo (1977) using transmission electron microscopy noted that spores "in the upper portion of the stalk develop into what appear to be normal spores while the segments of protoplasm beneath them develop into spore-like bodies" in Arcyria cinerea by the former and in Trichia decipiens by the latter "...the bodies are bigger and more densely packed in the base of the stipe than near the top." Rammeloo (1977) further states that "In the base these "cells" are angular in profile and cemented to each other by the walls they have in common, near the top they become spherical, with clearly individualized walls and with an ornamentation which gradually merges into the normal spore ornamentation (Fig. 1)."

These spore-like bodies have been a puzzle because attempts to germinate them have failed, their general mostly spherical shape resembles spores, but their much larger size (10)-12-30-(34) $\mu \mathrm{m}$ and smooth surfaces lacking ornamentation. Lado and Pando (1997) suggest a pre-spore development. The presence and absence of these spore-like bodies in the same genus needs more ultrastructural evidence to clarify their functional role in trichiaceous stalks.

The more correct structural term is "spore-like body" rather than "cells" to avoid confusion with cells of a living system that do not occur in myxomycete fruiting bodies. The term "cyst" is used in different ways in the myxomycete life cycle, for example, microcysts for encysted myxamoebae and spherules (macrocysts) for encysted plasmodial sclerotia. To avoid confusion with the same terms used in the myxomycete life cycle, spore-like bodies will be used in this paper.

Lado and Ronikier (2008) in a list of nivicolous myxomycete species from the Pyrenees, listed Arcyria versicolor as not strictly nivicolous. His study of nivicolous myxomycetes in the Spanish Guadarrama Mountains listed Arcyria versicolor, Prototrichia metallica (Berk.) Massee and Licea variabilis Schrad. as facultative species (Lado 2004). He has found fresh fruitings of Arcyria versicolor in August in the mountains near Madrid after rain showers (Lado pers. comm.).

Meyer has found Arcyria versicolor near melting snowbanks in the French Alps suggesting an obligate nivicolous species. In the Colorado Rocky Mountains there are generally two seasons when myxomycete fruiting bodies are found according to Mitchel et al. (1980): "1) at the edge of melting snowbanks in the spring and early summer; 2) during rainy periods in the late summer and early fall." Date and elevation are important field collection data because the snowbank nivicolous myxomycetes species are found in the foothills of the Rockies in early spring April to June, even late July, and the summer myxomycete fruitings start in June until November. This latter seasonal occurrence coincides with the summer rainy period in August and September (Mitchel et al. 1980). Colorado mountain collections of Arcyria versicolor near melting snowbanks appear to be obligate nivicolous species based on the specimens cited here. Arcyria versicolor fruiting bodies appear to persist longer 


\section{HERGARIUM OF}

THE NEW YORK GLTANICAL GARDEN

FUNGI DF CALIFORNIA, USA

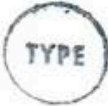

N.Y.B. G. No. 5207

TYPE

Arcyria versicolor Phil.

DETERMINEO GY

NEW YOAK BOTANICAL GARDEN

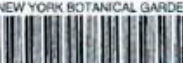

00834200

Harkness

A. IMAGED

TYPE OF:

Arcyria versicolor W. Phillips, Grevillea $\frac{\text { Ano. } 35): 1151877}{5(\text { no }}$

A

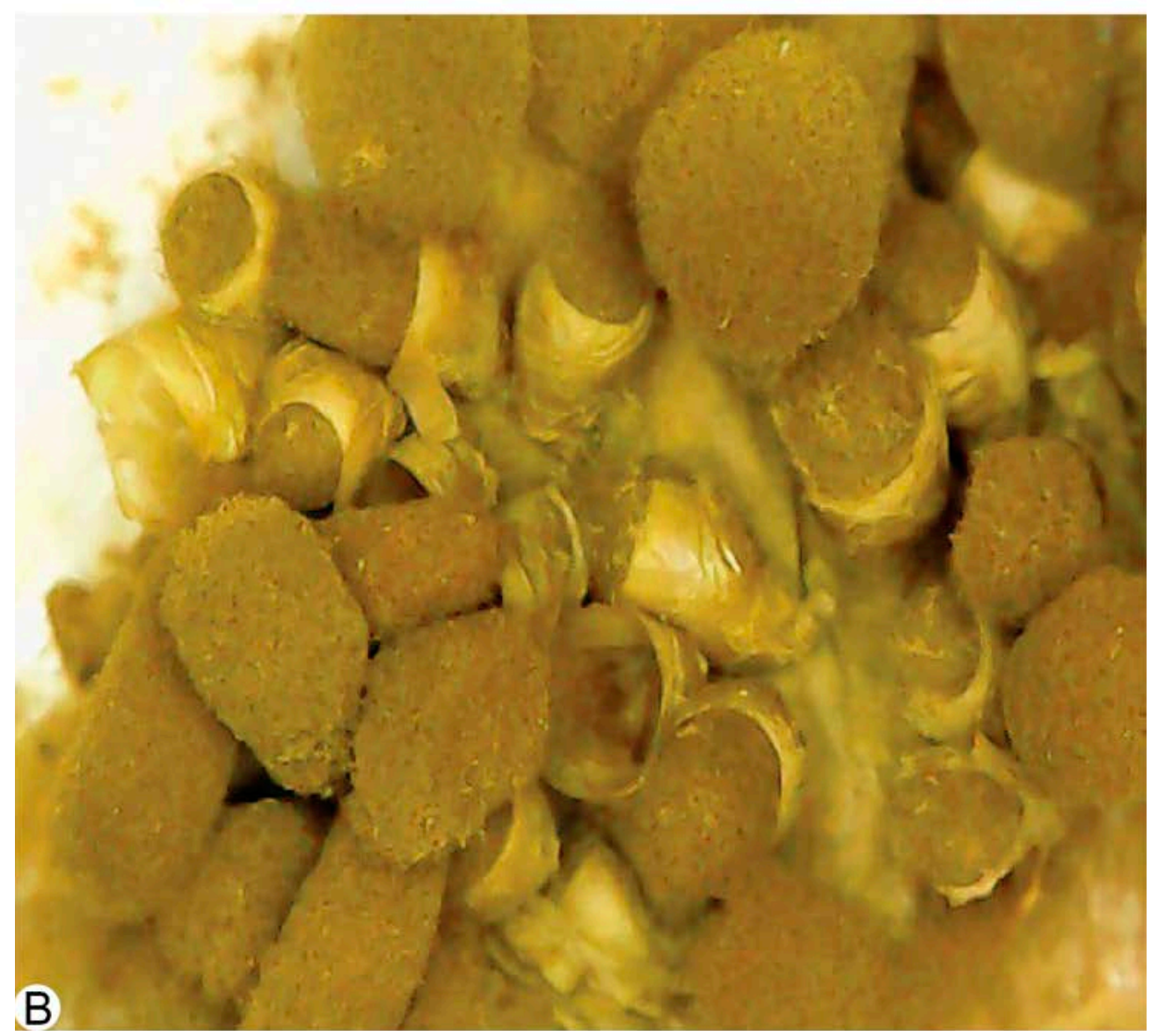

FIG. 8. NYBG Type Collection. A. Arcyria versicolor packet label. B. Habit photograph of Arcyria versicolor, NYBG No. 5207. Note yellow color of capillitum, calyculus, and circumscissle circular dehiscence 144 years after collection date. Capillitial mass retains tight sporangial shape after dehiscence. 


\section{HERGARIUM QF \\ THE NEW YORK GOTANICAL GARDEN \\ FUNGI DF CALIFORNIA, USA}

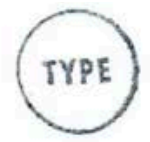

N. Y. B. G. No. 5209

\section{Arcyria vitellina Phil.}

On Pinus contorta.

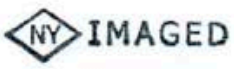

Sierra Nevada.

CaLlected BY Harkness

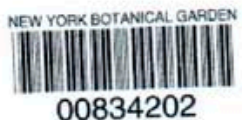

DETERMINED GY

TYPE OF:

Arcyria vitellina W. Phillips, Grevillea

5(no. 35$): 1151877$

A

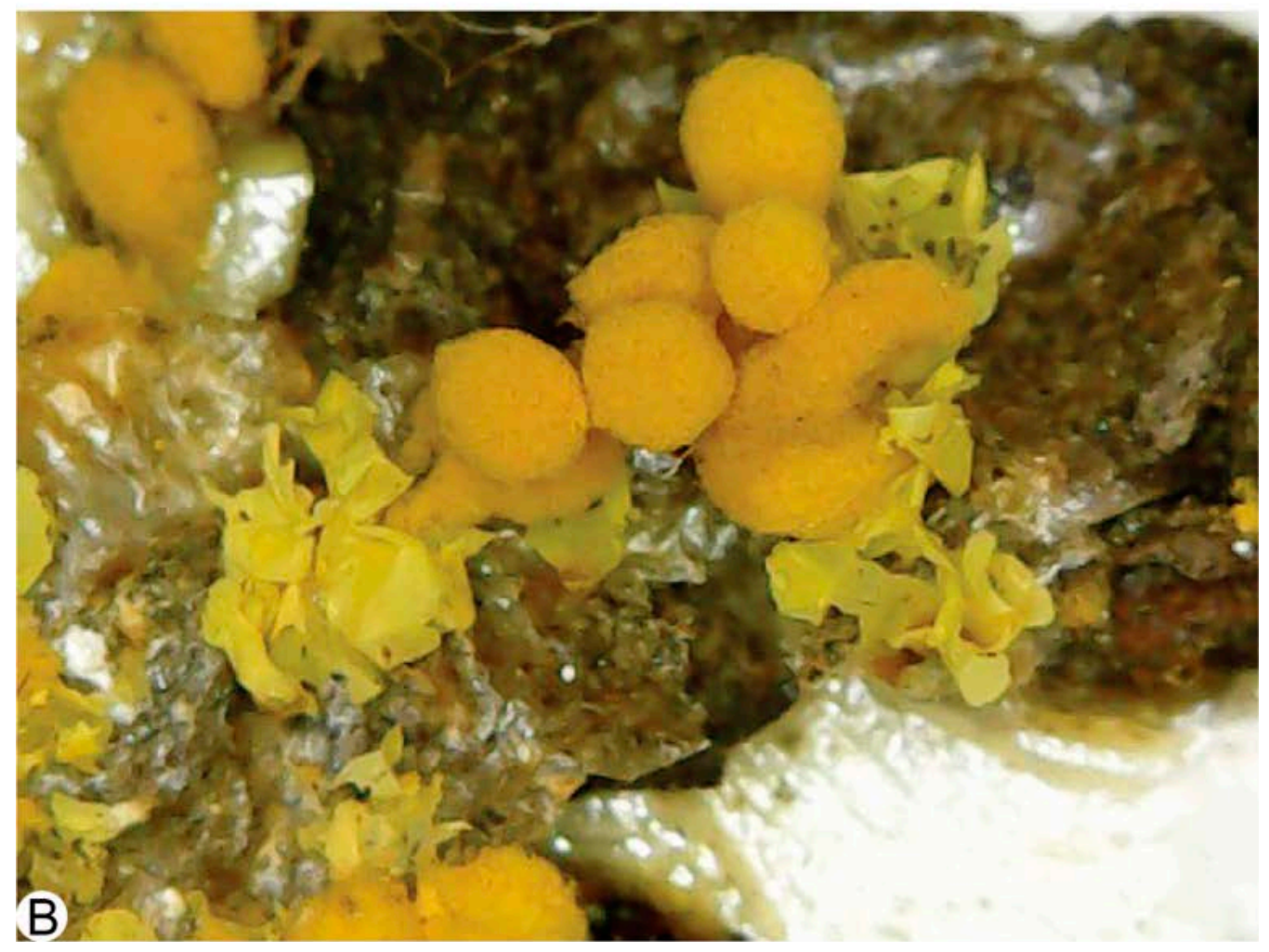

FIG. 9. NYBG Type Collection. A. Arcyria vitellina packet label. B. Habit photograph of Arcyria vitellina NYBG No. 5209. Note yellow capillitium, calyculus, and shredded torn dehiscence. 
(several weeks) under field conditions because of the protective calyculus that may account for the few collections in August. However, based on collection dates on the specimens cited here Arcyria versicolor is an obligate nivicolous myxomycete species.

\section{RESULTS AND DISCUSSION}

\section{Dark-spored nivicolous myxomycetes (Physarales and Stemonitales) versus light-spored nivicolous myxomycetes (Trichiales): impact of ultraviolet light}

The main environmental factors influencing the presence and development of nivicolous myxomycetes are: depth of snow cover, oscillating temperatures, light spectra, and availability of food for amoeboflagellates and plasmodia (Dahl et al. 2018; Schnittler et al. 2015). Another important factor that also should be considered, apparently not mentioned specifically heretofore, is ultraviolet light (UV). Melanized fungi become adapted with many more black or dark-walled, spored species surviving in extreme environments (extremophiles) of heat and cold temperatures (Belozerskaya et al. 2017; Gessler et al. 2014). Thus, the dark colored fungal species are more prevalent (greater numbers) in deserts and high elevation snow covered habitats. One would expect the dark-spored nivicolous myxomycete taxa to dominate in high elevation cold (snow-covered) mountainous environments. Marianne Meyer has kept yearly records of her nivicolous myxomycete collections in the French Alps Savoie region from 1979 to 2019 (Table 1).

These numbers suggest perhaps selection and survival value account for why the dark-spored nivicolous myxomycete taxa and collections at high elevation snow-covered sites in mountainous regions clearly exceed the light-spored number of taxa and collections in the same habitats. These differences may be attributed to melanin buffering against the effects of higher ultraviolet light absorption at higher elevations among other factors.

\section{CONCLUSIONS}

Observations, collection, and study of nivicolous myxomycete species by RLP during a 15-year period in VCNP has resulted in a better understanding of conditions that favor the development and fruiting of this special ecological group of myxomycetes in New Mexico. Remote high elevation mountainous areas are field sites

TABLE 1. Summary of Meyer's collections of dark-spored and light-spored nivicolous myxomycete taxa.

\begin{tabular}{|c|c|c|c|c|}
\hline Order & Genera & $\begin{array}{l}\text { Number of } \\
\text { Species }\end{array}$ & $\begin{array}{l}\text { Number of } \\
\text { Collections }\end{array}$ & Spore Color \\
\hline \multirow[t]{6}{*}{ Physarales } & & 33 & 8,900 & dark \\
\hline & Diderma & 8 & 3,500 & dark \\
\hline & Didymium & 5 & 1,500 & dark \\
\hline & Elaeomyxa & 1 & - & dark \\
\hline & Lepidoderma & 13 & 2,100 & dark \\
\hline & Physarum & 6 & 1,800 & dark \\
\hline \multirow[t]{6}{*}{ Stemonitales } & & 56 & 15,450 & dark \\
\hline & Comatricha & 8 & 700 & dark \\
\hline & Diacheopsis & 6 & 400 & dark \\
\hline & Enerthenema & 2 & 150 & dark \\
\hline & Lamproderma & 32 & 10,700 & dark \\
\hline & Meriderma & 7 & 3,500 & dark \\
\hline \multirow[t]{6}{*}{ Trichiales } & & 12 & 1,040 & light \\
\hline & Arcyria & 1 & 200 & light \\
\hline & Dianema & 5 & 80 & light \\
\hline & Hemitrichia & 2 & 60 & light \\
\hline & Perichaena & 1 & - & light \\
\hline & Trichia & 3 & 700 & light \\
\hline
\end{tabular}


usually difficult to access especially when roads or trails are snowbound during springtime. This limits access by myxomycete collectors unless they are willing to hike long distances and gravitate to productive collecting sites as the snow pack melts. Consequently, productive mountain myxomycete collection sites typically are visited on a hit or miss basis; therefore, missing daily changes as the snow melts, and the appearance of developing myxomycete plasmodia and fruiting bodies. Environmental parameters can be measured onsite by data loggers and visible changes in snow conditions recorded by video cameras. Aerial photography using flyover drones is another possible way to record ground surveys and melting snow packs. Thus, the studies by Schnittler et al. (2015) and Dahl et al. (2018) represent important experimental data gathered by data loggers and meteorological sources that measure climatic changes over time. Their findings show that snow depth, oscillating temperatures in specific ranges, and gradual melting of snow provides the best environmental conditions for predicting the occurrence of nivicolous myxomycete species. However, future experiments should test the importance of ultraviolet radiation and the role that this environmental factor plays in the development and distribution of nivicolous myxomycetes. Many mountainous regions are still relatively unexplored, including the Himalayas in Nepal, Kunlun in China, part of the Andes from Argentina to Venezuela, among others. This undiscovered nivicolous myxomycete biodiversity will lead to new species, provide comparisons of myxomycete taxa in different mountainous regions, and further document environmental conditions, including shifting climatic changes on a worldwide basis.

\section{ACKNOWLEDGMENTS}

Research products presented in this publication were generated with support from the George C. and Sue W. Sumner Molecular and Structural Laboratory at the Botanical Research Institute of Texas. This laboratory houses the Hitachi SU 3500 high resolution SEM. Renato Cainelli from Trieste, Italy graciously provided his collection data of Arcyria versicolor from California. His light microscope photographic images using multifocal imaging and computer stacking are as follows: Figs. 3A-E; Figs. 4B, C. RLP took photographs Figs. 1A, C-H, 8A, B, 9A, B. Marianne Meyer kindly shared her observations on the ecology of nivicolous myxomycetes and field collection data of Arcyria versicolor based on more than 40 years of study in the French Alps. She provided the photograph for Figure 3F. All of the LM photographs of the New Mexico Arcyria versicolor specimen were taken by Edward D. Forrester and Billy G. Stone took the SEM photographs. Bob O'Kennon is credited for taking habit photograph Fig. 4A of Arcyria versicolor. Ashley Bordelon took the photograph for Fig. 2, edited a prepublication manuscript, and assisted with herbarium specimens. Andrew Wilson assisted with the loan of Arcyria versicolor from the Denver Botanic Garden (DBG) and provided information on Sam Mitchel. Curators at the National Fungus Collections (BPI) and New York Botanical Garden assisted with the loan of myxomycete collections. Yuri Novozhilov contributed his observations of Arcyria versicolor in Russia. Peter Fritsch assisted with preparation of the SEM images and figures for publication. Thanks to two reviewers (Uno Eliasson and Yuri Novozhilov) who improved the organization and content of this paper. Special thanks go to the US Forest Service and National Park Service for permits VCT-2005RIM-002, VCT-2011-RIM-003 and VALL-2016-SCI-0021 issued to RLP.

\section{REFERENCES}

Belozerskaya, T.A., N. Natalya, N.N. Gessler, \& A.A. Aver'Yanov. 2017. Melanin. Pigments of fungi. Chapter 8, Fungal Metabolites Springer International Publishing, New York, U.S.A. Pp. 263-291.

Dahl, M.B., O. Shchepin, C. Schunk, A. Menzel, Y.K. Novozhilov, \& M. Schnittler. 2018. A four-year survey reveals a coherent pattern between occurrence of fruit bodies and soil amoebae populations for nivicolous myxomycetes. Sci. Rep. 8:11662.

Емото, Y. 1977. The myxomycetes of Japan. Sangyo Tosho Publishing Co., Tokyo, Japan.

Evenson, V.S, A.W. WILSON, \& S.T. BATES. 2018. Of medicine, mountains, and mushrooms: The life and legacy of Sam Mitchel. Fungi 10(4):28-36.

FARR, M.L. 1976. Myxomycetes. Flora Neotropica 16:1-305. 
Gessler, N.N., A.S. Egorova, \& T.A. Belozerskaya. 2014. Melanin pigments of fungi under extreme environmental conditions (Review). Appl. Biochem. Microbiol. 50:105-113.

HAGELSTEIN, R. 1944. The Mycetozoa of North America. Mineola, New York, U.S.A.

KeLleR, H.W. 2012. Myxomycete history and taxonomy: Highlights from the past, present, and future. Mycotaxon 122:369-387.

Keller, H.W. \& K.L. Braun. 1999. Myxomycetes of Ohio:Their systematics, biology and use in teaching. Bull. Ohio Biol. Surv. $13(2): 1-182$.

Keller, H.W., H.C. AldRich, \& T.E. Brooks. 1973. Corticolous myxomycetes II: Notes on Minakatella longifila with ultrastructural evidence for its transfer to the Trichiaceae. Mycologia 65:768-778.

KelleR, H.W. \& T.E. Brooks. 1975. Corticolous myxomycetes III: A new species of Badhamia. Mycologia 67:1218-1222.

Keller, H.W., S.E. Everhart, \& C.M. Kilgore. 2017. The myxomycetes: Basic biology, life cycles, genetics and reproduction. In: Stephenson, S. \& C. Rojas, eds. "Myxomycetes: Biology, systematics, biogeography and ecology," Chapter 1. Elsevier, Atlanta, Georgia, U.S.A. Pp. 1-40.

Keller, H.W. \& V.M. MarShall. 2019. A new iridescent corticolous myxomycete species (Licea: Liceaceae: Liceales) and crystals on American elm tree bark in Texas, U.S.A. J. Bot. Res. Inst. Texas 13(2):367-386.

KoWALSKI, D.T. 1967. New records of myxomycetes from California. Madroño19 (2):43-46.

KoWALSKI, D.T. 1975. The myxomycete taxa described by Charles Meylan. Mycologia 67:448-494.

LAdO, C. 2004. Nivicolous myxomycetes of the Iberian Peninsula: Considerations on species richness and ecological requirements. Syst. Geogr. 74:143-157.

LADO, C. 2005-2020. An online nomenclatural information system of Eumycetozoa. Real Jardin Botanico, CSIC, Madrid, Spain. Last consulted, 12 June 2020.

LADO, C. \& F. PANDo. 1997. Flora Mycologica Iberica, myxomycetes, 1. Ceratiomyxales, Echinosteliales, Liceales, Trichiales. 2:1-323. Madrid, Spain.

LADO, C. \& A. RonikIER. 2008. Nivicolous myxomycetes from the Pyrenees: Notes on taxonomy and species diversity Part I. Physarales and Trichiales Nova Hedwigia 87:337-360.

LinNAEUS, C. 1753. Species plantarum. 2 vols. Salvius. Stockholm. Facsimile edition. 1957-1959. Ray Society, London.

LISTER, A. 1894. A monograph of the Mycetozoa. Being a descriptive catalogue of the species in the Herbarium of the British Museum, Ed, 1, Printed by Order of the Trustees, London, UK, 1911. Ed. 2, Revised by G. Lister, 1925. Ed. 3, Revised by G. Lister.

MACBRIDE, T.H. 1899. The North American slime-moulds, being a list of all species of myxomycetes hitherto described from North America, including Central America. The Macmillan Company, New York, U.S.A.

MacBride, T.H. 1905. The slime moulds of New Mexico. Proc. lowa Acad. Sci. 12:33-38.

MACBRIDE, T.H. 1914. Mountain myxomycetes. Mycologia 6:146-149.

MACBRIDE, T.H. 1922. The North American slime-moulds. A descriptive list of all species of myxomycetes hitherto reported from the continent of North America, with notes on some extra-limital species. Ed 2. The Macmillan Company, New York, U.S.A.

MACBRIDE, T.H. \& G.W. MARTIN. 1934. The myxomycetes. The Macmillan Company, New York, U.S.A.

Martin, G.W. 1949. Fungi, myxomycetes, Ceratiomyxales, Liceales, Trichiales, Stemonitales, Physarales. In: N. Amer. Fl. $1(1): 1-151$.

Martin, G.W. \& C.J. Alexopoulos. 1969. The myxomycetes. University of lowa Press, lowa City, U.S.A.

MASSEE, G. 1892. A monograph of the Myxogastres. Methuen \& Co., London, UK.

Mims, C.W. \& M.A. Rogers. 1975, A light and electron microscope study of stalk formation in the myxomycete Arcyria cinerea. Mycologia 67:638-649.

Mitchel, D.H., S.W. Chapman, \& L. FarR. 1980. Notes on Colorado fungi, myxomycetes. Mycotaxon 10(2):299-349.

Moreno, G., A. CAstillo, \& R. Price. 2008. Comatricha calderaensis, a new species of nivicolous myxomycete from the Valles Caldera National Preserve, USA. Bol. Soc. Micol. Madrid 32:106-111.

Moreno, G., Á. López-Villalba, \& A. CAstillo. 2019. Some nivicolous myxomycetes from Colorado and New Mexico (USA) sent by Ted Stampfer. Bol. Soc. Micol. Madrid 43:5-15.

Neubert, H., W. Nowotny, \& K. Baumann. 1993.Die Myxomyceten, Band 1. Karlheinz Baumann Verlag, Gomaringen, Germany. PHILLIPS, W. 1877. Fungi of California and the Sierra Nevada Mountains. Grevillea 5:113-118.

Poulain, M., M. Meyer, \& M. Bozonnet. 2011. Les Myxomycètes. Fédération mycologique et botanique Dauphiné-Savoie, Sevier, France. Vol. 2. 
PRICE, R.L. 1971. The myxomycetes of Montane northern New Mexico. Master of Science Thesis. Utah State University, Logan, Utah, U.S.A.

Price, R.L., H.W. Keller, \& T. Stampfer. 2010. Valles Caldera National Preserve: Protecting a cryptogam paradise and a geologic jewel in New Mexico. Inoculum 61(2):1-4.

Rammeloo, J. 1977. Notes concerning the spore-like bodies in myxomycetes. Bull. Jard. Bot. Natl. Belgique 47:449-458.

Schnittler, M., D.A. Erastova, O.N. Shchepin, E. Heinrich, \& Y.K. Novozhilov. 2015. Four years in the Caucasus - observations on the ecology of nivicolous myxomycetes. Fungal Ecol. 14:105-115.

StuRGIS, W.C. 1907. The myxomycetes of Colorado. Colorado College Publ. Sci. Ser. 12(1):1-43.

SundberG, W.J. \& H.W. Keller. 1996. Myxomycetes: Some tools and tips on collection, care, and use of specimens. Inoculum 47(4):12-14. 